\title{
Potential Nutraceuticals for COVID-19
}

This article was published in the following Dove Press journal:

Nutrition and Dietary Supplements

\section{Sayali Savant \\ Shraddha Srinivasan \\ Anil Kumar Kruthiventi (DD}

Arna Immuno Ingredients Private Limited, Mumbai, Maharashtra, India
Correspondence: Anil Kumar Kruthiventi Arna Immuno Ingredients Private Limited, Ist Floor, 4I/44, Minoo Desai Marg. Colaba, Mumbai, 400005, India

$\mathrm{Tel}+9 \mid 954550048$ I

Fax +91 22674900001

Email anil.kumar@arnaimmuno.com
Abstract: SARS-CoV-2 infection has caused, and is continuing to cause, considerable human suffering. Studies on the viral pathogenesis has resulted in convergent findings from several lines of evidence on the entry and spread of the virus in the host. These studies have also revealed a strong association between innocuous inflammation, ageing and metabolic disorders, with SARS-CoV-2 infection and its prognosis. Diet helps modulate inflammation, and nutraceuticals can inhibit viral entry. Hence, we have collated literature on antiviral nutraceuticals effective against other similar coronaviruses. The objective of this study is to comprehensively review available information on the antiviral activity of nutraceuticals and to discuss the implications of these findings in designing a diet that would boost the innate immunity and act as preventive care against COVID-19. This review highlights the fundamental impact of nutraceuticals and diet on inhibition of viral entry and provides a new perspective on the prevention and treatment of COVID-19.

Keywords: SARS-CoV-2, diet, plant protease inhibitors, polyphenols, bioactive peptides

\section{Introduction}

SARS-CoV-2 has disrupted global health and economic wellbeing since the beginning of 2020. The regional office of World Health Organization (WHO) in China was first alerted to the virus infection in Wuhan on December 31, 2019 and termed the infection as an epidemic on March 11, 2020. Since then, laboratories across the globe have been collaborating to develop vaccines and therapeutic agents for this novel coronavirus.

The SARS-CoV-2 belongs to a group of viruses called the coronaviruses. These are single-stranded, positive sense, RNA viruses, enveloped in a helical capsid with spike shaped trans-membrane proteins. They can further be classified into four subtypes: alpha, beta, delta, and gamma. ${ }^{1}$ The coronaviruses are capable of infecting both humans and animals and have the ability to jump the species barrier thereby accelerating the spread of the disease into an epidemic or a pandemic. The severe acute respiratory syndrome coronaviruses (SARS-CoV and SARS-CoV2) and Middle East respiratory syndrome coronavirus (MERS-CoV) are the three highly pathogenic coronaviruses. The remaining four (HCoV-NL63, HCoV-229E. HCoV-OC43, and HCOV-HKU1) human coronaviruses are less virulent. ${ }^{2}$

What makes the SARS-CoV-2 threatening is not just the viral infection but the accompanying cytokine storm and other associated comorbidities. Analysis of clinical data from 326 confirmed COVID-19 patients in Shanghai revealed IL-6 and IL-8 to show the most significant changes and the levels of these two interleukins inversely co-related with the lymphocyte count. ${ }^{3}$ A reduced $\mathrm{CD} 4^{+} / \mathrm{CD} 8^{+}$ ratio is also a manifestation of the disease. A detailed explanation of the host immune response and the viral evasion methods follows in the later part of this paper. 
Initial genomic phylogeny testing revealed that the SARS-CoV-2 virus shared about $79 \%$ and $50 \%$ gene similarity with SARS-CoV and MERS-CoV, respectively. ${ }^{2}$ Therefore, the initial treatment has included therapeutics known to be effective against SARS-CoV and MERS-CoV for SARS-CoV-2.

In this article we give an overview of the present understanding of the viral lifecycle and host immune responses, which would form the basis for selecting nutraceuticals and natural products that can be potentially explored both as therapeutic and preventive interventions for the SARS-CoV-2 infection.

\section{Virus Replication Cycle and Potential Therapeutic Targets}

Understanding the cellular basis of SARS-CoV-2 infection could reveal treatments that prevent the development to a severe disease, and thus reduce mortality. Figure 1 represents a simplified illustration of the infection cycle of SARS-CoV-2.

The spike glycoprotein (S) is a $180-200 \mathrm{kDa}$ transmembrane homotrimer which recognizes and binds to the host angiotensin-converting enzyme 2 (ACE2) receptors. ${ }^{4}$ The $\mathrm{S}$ protein can further be subdivided into $\mathrm{S} 1$ (the homotrimer head) and the S2 protein (the tail part). Figure 2 gives an enlarged view of the spike protein of the virus. ACE2 is a human receptor largely found in the respiratory and intestinal epithelial cells but it is also present in the kidney, heart, brain, etc. ACE2 has a short C-terminal intracellular domain and a long N-terminal extracellular domain, to which the $\mathrm{S} 2$ head of the virus binds. $^{5}$ The spike protein mediates two essential events: binding to ACE2 by the amino-terminal region and fusion of viral and cellular membranes through the carboxyl terminal region.

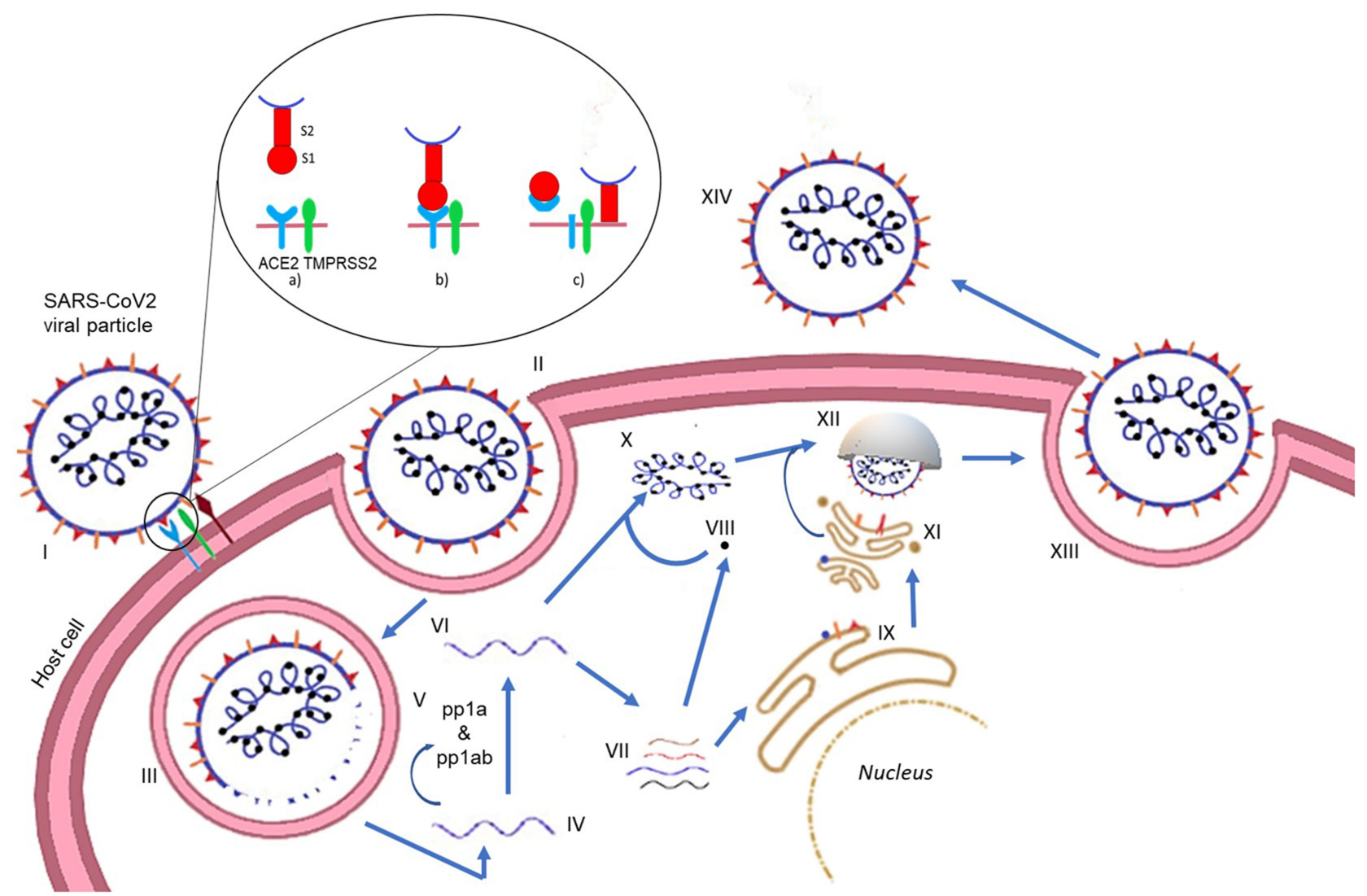

Figure I SARS-CoV-2 replication cycle. (I) The spike protein (S) on SARS-CoV-2 facilitates attachment to the host cell through the ACE2, TMPRSS2. The S protein has two subunits, SI and S2 (a). The SI subunit attaches to ACE2 (b) following which TMPRSS2 cleaves ACE2 (c). The S2 subunit facilitates fusion of the viral particle with the host cell membrane thereby leading to viral entry (c). (II and III) Alternatively, the viral entry can also occur via endocytosis. (IV) Release of the viral genome (+ strand) after entry. (V) Translation of the strand leads to the formation of polyproteins (Ppla and Pplab) which are cleaved by the main protease (MPro) and papain-like protease (PLPro) into the nonstructural proteins (nsps). (VI) The genome is replicated by RdRp. (VII) The transcription of the genome gives the subgenomic transcripts which encode the structural proteins. (VIII) The nucleocapsid is translated in the cytoplasm. (IX) The other structural proteins are translated in the endoplasmic reticulum (ER). (X) The nucleocapsid and the genomic strand form the genomic RNA. (XI) The structural proteins are glycosylated in the golgi bodies. (XII) A budding vesicle forms with the virion particles assembling. (XIII) Exocytosis of the assembled viral particle occurs. (XIV) The newly released viral particles can now infect other host cells. 


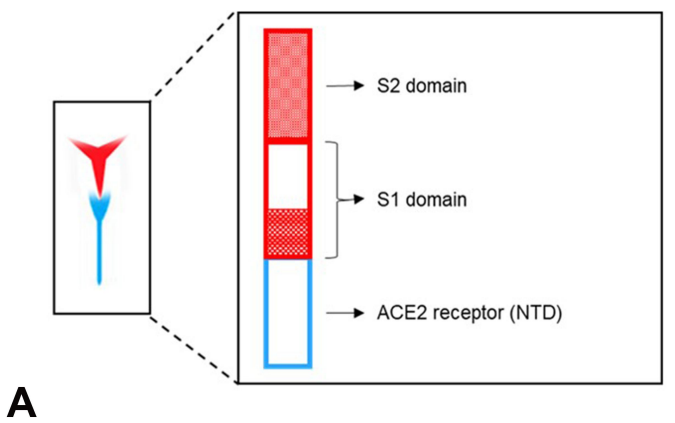

B

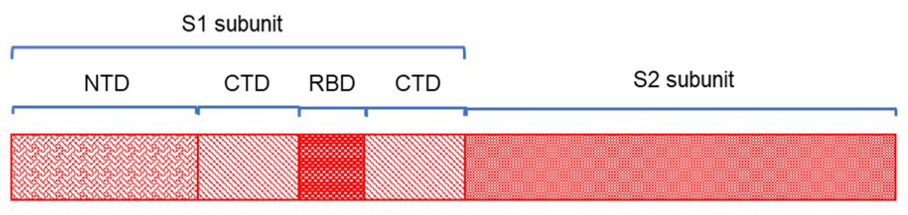

Figure 2 Enlarged view of spike protein. (A) The binding of the $\mathrm{S}$ protein to the ACE2 receptor occurs at the receptor binding domain (RBD site) of the SI domain, binding to the $\mathrm{N}$-terminal domain of the host receptor, $(\mathbf{B})$ the amino- or N-terminal domain (NTD), carboxy- or C-terminal domain (CTD) and the receptor binding domain (RBD) of the SI subunit and the S2 subunit that constitute the spike protein (S).

The spike protein bound to ACE2 can be cleaved by two enzymes, the transmembrane serine protease 2 (TMPRSS2) at the S2 site and by furin at the S1/S2 connection site. ${ }^{6}$ TMPRSS2 acts at monobasic cleavage sites, ie it cleaves at a single arginine or lysine residue. Furin, however, cleaves at a polybasic site. ${ }^{6}$ Infection of lung cells requires host proteolytic activation of spike at a polybasic furin cleavage site. Cleavage by the furin protease, therefore, can expand SARS-CoV-2 cell tropism and may have facilitated transmission from bats to humans. ${ }^{2}$ SARS-CoV-2 tropism is, therefore, dependent on expression of cellular proteases, as well as ACE2.

However, TMPRSS2 is not expressed in all the cells expressing ACE2 suggesting the existence of alternative pathways for viral entry such as through use of cathepsin $\mathrm{L}$ and cathepsin B. ${ }^{7}$ However, this is a matter of debate since studies have also found that cathepsins are not required for SARS-CoV-2 infection. ${ }^{6}$ Post-cleavage, the virus can enter the host cells either through membrane fusion or through endocytosis. ${ }^{5}$

Two-thirds of the viral genome produces two polypeptides, pp1a and pplab which are processed by the viral proteases chymotrypsin like cysteine protease (3CLPro) or main protease (MPro) and one or two papain-like proteases into 16 nonstructural proteins (nsps) that play diverse roles in the subsequent viral replication and infection. ${ }^{8}$ The remaining one-third of the genome encodes for the main viral proteins namely, the spike protein, the nucleocapsid protein, the membrane protein, and the envelope protein. Replication occurs within double membrane vesicles (DMVs) which comprise RNA-dependent RNA polymerase (RdRp) and the nsps. The sub-genomic particles manufactured here then move towards the endoplasmic reticulum golgi complex compartment where they undergo maturation. The virulent particles present in vesicles are further released through the process of exocytosis. ${ }^{1}$ Thus, the life cycle of the virus with the host consists of five steps: attachment, penetration, biosynthesis, maturation, and release.

Therapeutics, therefore, can target either the viral proteins or the host proteases. Since the host proteases play multiple roles within the human body, targeting the host proteases may also interfere with other physiological activities in the host body and so caution must be exerted in this approach. Hence, viral proteins seem more attractive and safe targets.

In case of the SARS-CoV-2 virus, the following have been identified as the potential therapeutic targets: the spike glycoprotein (S), the envelope glycoprotein (E), the nucleocapsid protein $(\mathrm{NP})$, the membrane protein $(\mathrm{M})$, the papain like protease (PLPro) or the chymotrypsin like cysteine protease (CLPro), (also known as the main protease MPro) and the RNA dependent RNA polymerase (RdRp). In addition to this, certain nsps could also be targeted. The nsp13 helicase is an important component for replication of the virus which is target for many virus inhibitors. ${ }^{9}$ Nsp10 plays a major role in viral transcription wherein nsp14 3'-5' exoribonuclease and nsp16 2'-O methyltransferase are stimulated by playing a lead role in viral mRNAs cap methylation. ${ }^{10}$

The following sections give an overview of the different plant-derived ingredients and more specifically nutraceuticals, that can potentially be developed into therapeutic molecules targeting one or more multiple targets discussed above.

\section{Nutraceuticals and Coronavirus Infection}

Nutraceuticals is a portmanteau of "nutrition" and "pharmaceuticals". The structure of the word itself directs us towards 
the dual use of these molecules: for preventive health care (source of nutrients that will prevent the occurrence of disease) and as therapeutic molecules (like pharmaceuticals taken to cure a disorder or disease). Table 1 mentions the details of a few nutraceuticals that have been tested against the earlier coronaviruses SARS-CoV and MERS-CoV.

$\mathrm{Yi}$ et $\mathrm{al}^{11}$ performed in vitro and animal testing on multiple small molecules and found luteolin to be effective in blocking the S2 protein of the SARS-CoV virus. The SARS-CoV and SARS-CoV-2 S proteins share about $76 \%$ amino acid similarity. ${ }^{7}$ Since both the viruses bind to the same host receptor, there is an increased likelihood that molecules that block or interact with SARS-CoV $\mathrm{S}$ protein will most likely be effective against SARS-CoV-2 S protein. The authors also tested the effect of quercetin using a pseudotype virus assay, the rationale being that quercetin shared structural similarity to luteolin. Quercetin is an ingredient of antioxidant and antiallergy medicines that had been approved by the US Food and Drug Administration (FDA; the national drug code numbers of the medicines are 65448-3085, 65448-3005).

Table I Experimentally Tested Nutraceuticals Against Different Coronavirus and Host Proteins

\begin{tabular}{|c|c|c|c|c|c|}
\hline S. No. & Molecule & Target & $\begin{array}{l}\text { Type of Studyl } \\
\text { Techniques Used }\end{array}$ & Results & $\begin{array}{l}\text { Study, } \\
\text { Year, } \\
\text { Reference }\end{array}$ \\
\hline I & Luteolin & $\begin{array}{l}\text { SARS- } \\
\text { CoV S2 } \\
\text { protein }\end{array}$ & $\begin{array}{l}\text { - Frontal-affinity chromato- } \\
\text { - graphy-mass spectrometry } \\
\text { - HIV-luc/SARS pseudotype } \\
\text { virus assay } \\
\text { - MTT assay with wild-type } \\
\text { SARS-CoV }\end{array}$ & $\begin{array}{l}\text { - Luteolin-inhibited SARS-CoV infection in a dose-depen- } \\
\text { dent manner. } \\
\text { - } \mathrm{EC}_{50} \text { was } 10.6 \mu \mathrm{M} . \mathrm{CC}_{50} \text { was } 0.155 \mathrm{mM} \text {. LD } \mathrm{LD}_{50} \text { in mice was } \\
232.2 \mathrm{mg} / \mathrm{kg}\end{array}$ & $\begin{array}{l}\text { Yi et al, } \\
2004^{\prime \prime}\end{array}$ \\
\hline 2 & Quercetin & $\begin{array}{l}\text { SARS- } \\
\text { CoV S2 } \\
\text { protein }\end{array}$ & $\begin{array}{l}\text { HIV-luc/SARS pseudotype } \\
\text { virus assay }\end{array}$ & $\mathrm{EC}_{50}$ of $83.4 \mu \mathrm{M}$ and $\mathrm{CC}_{50}$ of $3.32 \mathrm{mM}$ & $\begin{array}{l}\text { Yi et al, } \\
2004^{\prime \prime}\end{array}$ \\
\hline 3 & $\begin{array}{l}\text { GCG } \\
\text { (gallocatechin } \\
\text { gallate) }\end{array}$ & $\begin{array}{l}\text { SARS- } \\
\text { CoV } \\
3 \text { CLPro }\end{array}$ & $\begin{array}{l}\text { - Expression of recombinant } \\
\text { 3CLPro in Pichia pastoris } \\
\text { and its inhibition. } \\
\text { - Molecular docking }\end{array}$ & $\begin{array}{l}\text { - } 91 \% \text { inhibition by } 200 \mu \mathrm{M} \text {. } \\
\text { - } \mathrm{IC}_{50} \text { of } 47 \mu \mathrm{M} \text {. } \\
\text { - Binding energy of }-14 \mathrm{kcal} / \mathrm{mol}\end{array}$ & $\begin{array}{l}\text { Nguyen et } \\
\text { al, } 2012^{14}\end{array}$ \\
\hline 4 & Quercetin & $\begin{array}{l}\text { SARS- } \\
\text { CoV } \\
3 \text { CLPro }\end{array}$ & $\begin{array}{l}\text { - Expression of recombinant } \\
\text { 3CLPro in Pichia pastoris } \\
\text { and its inhibition. } \\
\text { - Molecular docking }\end{array}$ & $\begin{array}{l}\text { - } 80 \% \text { inhibition at } 200 \mu \mathrm{M} \text {. } \\
\text { - } \mathrm{IC}_{50} \text { of } 23.8 \mu \mathrm{M} \\
\text { - Binding energy }-10.2 \mathrm{kcal} / \mathrm{mol}\end{array}$ & $\begin{array}{l}\text { Nguyen et } \\
\text { al, } 2012^{14}\end{array}$ \\
\hline 5 & EGCG & $\begin{array}{l}\text { SARS- } \\
\text { CoV } \\
3 \text { CLPro }\end{array}$ & $\begin{array}{l}\text { - Expression of recombinant } \\
\text { 3CLPro in Pichia pastoris } \\
\text { and its inhibition. } \\
\text { - Molecular docking }\end{array}$ & $\begin{array}{l}\text { - } 85 \% \text { inhibition at } 200 \mu \mathrm{M} \text {. } \\
\text { - } \mathrm{IC}_{50} \text { of } 73 \mu \mathrm{M} \\
\text { - Binding energy }-1 \mathrm{I} .7 \mathrm{kcal} / \mathrm{mol}\end{array}$ & $\begin{array}{l}\text { Nguyen et } \\
\text { al, } 2012^{14}\end{array}$ \\
\hline 6 & Resveratrol & $\begin{array}{l}\text { MERS- } \\
\text { CoV } \\
\text { NP }\end{array}$ & $\begin{array}{l}\text { - MTT assay using vero-E6 } \\
\text { cell line } \\
\text { - Nucleocapsid protein } \\
\text { staining }\end{array}$ & $\begin{array}{l}\text { - Found to be effective in the } 125-250 \mu \mathrm{M} \text { range on viral } \\
\text { titre as well as viral RNA amount. } \\
\text { - Inhibits caspase } 3 \text { cleavage. }\end{array}$ & $\begin{array}{l}\text { Lin et al, } \\
2017^{12}\end{array}$ \\
\hline 7 & Hesperetin & $\begin{array}{l}\text { SARS- } \\
\text { CoV } \\
3 \text { CLPro }\end{array}$ & $\begin{array}{l}\text { Cell free and cell-based } \\
\text { cleavage assays }\end{array}$ & $\begin{array}{l}I C_{50} \text { of } 60 \mu \mathrm{M} \text { in cell free assay, } I C_{50} \text { of } 8.3 \mu \mathrm{M} \text { in cell-based } \\
\text { assay and a } C C_{50} \text { of } 2718 \mu \mathrm{M}\end{array}$ & $\begin{array}{l}\text { Lin et al, } \\
2005^{15}\end{array}$ \\
\hline 8 & Quercetin & $\begin{array}{l}\text { ACE2 } \\
\text { and } \\
\text { FURIN }\end{array}$ & $\begin{array}{l}\text { - Gene silencing } \\
\text { - Expression studies } \\
\text { - Transgenic mouse models }\end{array}$ & $\begin{array}{l}\text { - Quercetin affected ACE2 expression. } \\
\text { - In addition, it was found to alter the expression of } 98 \text { of } \\
332(30 \%) \text { genes encoding human proteins that serve as } \\
\text { target for the SARS-CoV-2. }\end{array}$ & $\begin{array}{l}\text { Glinsky, } \\
2020^{16}\end{array}$ \\
\hline
\end{tabular}


This strategy by Yi et $\mathrm{al}^{11}$ can be extended to current search by identifying structures similar to the ones that are showing promise in silico and in vitro, but already have a generally recognized as safe (GRAS) status owing to their documented food or medicinal use. This can drastically reduce the time required for regulatory approvals and give more confidence for clinical trials. In fact, a similar strategy was earlier used by Lin et $\mathrm{al}^{12}$ when they decided to test the efficacy of resveratrol, a stilbene derivative, based on earlier studies that showed antiviral activities on SARS-CoV.

The coronavirus main protease (MPro or 3CLPro) structural backbone and active site conformation are conserved despite sequence variations. ${ }^{13}$ Hence, nutraceuticals such as epigallocatechin gallate (EGCG), gallocatechin gallate (GCG), hesperetin, quercetin, which were previously shown to be effective against SARS-CoV 3CLPro can be tested for their efficacy in SARS-CoV-2 infection. Nguyen et $\mathrm{al}^{14}$ found that a galloyl moiety present at the $3^{\prime} \mathrm{OH}$ position of a potential inhibitor, belonging to the flavonoid class, is crucial for inhibition of 3CLPro in SARS-CoV. Enzyme kinetics suggested that GCG competitively inhibited 3CLPro with an inhibition constant of $25 \mu \mathrm{M}$.

As seen in Table 1, quercetin seems to have multiple targets of action and may prove to be a better candidate molecule for therapeutic development. Administration of quercetin $(1000 \mathrm{mg})$ showed a decrease in the incidence and extent of upper respiratory tract infections (URTIs). Abian et $\mathrm{al}^{17}$ identified quercetin as a reasonably potent inhibitor of SARS-CoV-2 3CLpro protease, with the inhibition constant being $-\mathrm{K}_{\mathrm{i}} \sim 7 \mu \mathrm{M}$. Quercetin also modulates the cellular unfolded protein response (UPR). As coronaviruses can utilize the UPR to complete different stages of the viral life cycle during infection, this is an important finding. ${ }^{18}$ Early clinical data suggests that quercetin has broad antiviral property and acts at various steps of viral life cycle. As an FDA-approved drug ingredient, with potent antiviral action, quercetin offers great promise as a potential drug candidate in the clinical treatment of SARS.

\section{In silico Studies Reveal Potential Therapeutic Nutraceuticals}

Given the importance of rapid generation of lead compounds, many authors have used in silico docking and modelling studies to generate a library of potential therapeutic lead molecules targeting different stages of the viral infection life cycle, some of which have been collated in Table 2. It is interesting to observe the structural similarities among these molecules-having a catechol/

Table 2 Potential Nutraceutical Therapeutic Targets as Revealed by in silico Studies

\begin{tabular}{|c|c|c|c|c|}
\hline S. No. & Molecule & Target & Binding Energy $\Delta \mathbf{G}$; Inhibition Constant $K_{i}$ & Study, Year, Reference \\
\hline I & EGCG & MPro & $\Delta \mathrm{G}:-9.30 \mathrm{kcal} / \mathrm{mol} ; \mathrm{K}_{\mathrm{i}}: 0.152 \mu \mathrm{M}$ & Khan et al, $2020^{19}$ \\
\hline 2 & Myricetin & S & $\Delta \mathrm{G}:-6.14 \mathrm{kcal} / \mathrm{mol} ; \mathrm{K}_{\mathrm{i}}: 31.32 \mu \mathrm{M}$ & Khan et al, $2020^{19}$ \\
\hline 3 & Quercetin & S & $\Delta \mathrm{G}:-6.14 \mathrm{kcal} / \mathrm{mol} ; \mathrm{K}_{\mathrm{i}}: 31.32 \mu \mathrm{M}$ & Khan et al, $2020^{19}$ \\
\hline 4 & Curcumin & MPro & $\Delta \mathrm{G}:-6.07 \mathrm{kcal} / \mathrm{mol} ; \mathrm{K}_{\mathrm{i}}: 37.57 \mu \mathrm{M}$ & Khan et al, $2020^{19}$ \\
\hline 5 & Curcumin & NP & $\Delta \mathrm{G}:-8.75 \mathrm{kcal} / \mathrm{mol} ; \mathrm{K}_{\mathrm{i}}: 0.39 \mu \mathrm{M}$ & Suravajhala et al, $2020^{10}$ \\
\hline 6 & Curcumin & Nsplo & $\Delta \mathrm{G}:-7.85 \mathrm{kcal} / \mathrm{mol} ; \mathrm{K}_{\mathrm{i}}: 1.77 \mu \mathrm{M}$ & Suravajhala et al, $2020^{10}$ \\
\hline 7 & $\delta$ - viniferin & MPro & $\Delta \mathrm{G}:-8.4 \mathrm{kcal} / \mathrm{mol}$ & Joshi et al, $2020^{13}$ \\
\hline 8 & $\delta$ - viniferin & $\operatorname{RdRp}$ & $\Delta \mathrm{G}:-8.3 \mathrm{kcal} / \mathrm{mol}$ & Joshi et al, $2020^{13}$ \\
\hline 9 & $\delta$ - viniferin & Human ACE2 receptor & $\Delta \mathrm{G}:-8.4 \mathrm{kcal} / \mathrm{mol}$ & Joshi et al, $2020^{13}$ \\
\hline \multirow[t]{3}{*}{10} & Myricitrin & MPro & $\Delta \mathrm{G}:-8.9 \mathrm{kcal} / \mathrm{mol}$ & Joshi et al, $2020^{13}$ \\
\hline & Myricitrin & $\operatorname{RdRp}$ & $\Delta \mathrm{G}:-7.9 \mathrm{kcal} / \mathrm{mol}$ & Joshi et al, $2020^{13}$ \\
\hline & Myricitrin & Human ACE2 receptor & $\Delta \mathrm{G}:-7.5 \mathrm{kcal} / \mathrm{mol}$ & Joshi et al, $2020^{13}$ \\
\hline II & Carnosol & MPro & $\Delta \mathrm{G}:-8.2 \mathrm{kcal} / \mathrm{mol} ; \mathrm{K}_{\mathrm{i}}: 0.97 \mu \mathrm{M}$ & Umesh et al, $2020^{20}$ \\
\hline 12 & Rosmanol & MPro & $\Delta \mathrm{G}:-7.99 \mathrm{kcal} / \mathrm{mol} ; \mathrm{K}_{\mathrm{i}}: 1.38 \mu \mathrm{M}$ & Umesh et al, $2020^{20}$ \\
\hline 13 & Silibinin & $\operatorname{RdRp}$ & NA & Bosch-Barrera et al, $2020^{21}$ \\
\hline 14 & Rutin & MPro & $\Delta \mathrm{G}-8.67 \mathrm{kcal} / \mathrm{mol}$ & Hu et al, $2020^{22}$ \\
\hline 15 & Mangiferin & S & $\Delta \mathrm{G}:-7.5 \mathrm{kcal} / \mathrm{mol} ; \mathrm{K}_{\mathrm{i}}: 3.16 \mu \mathrm{M}$ & Kar et al, $2020^{23}$ \\
\hline 16 & Mangiferin & MPro & $\Delta \mathrm{G}:-7.8 \mathrm{kcal} / \mathrm{mol} ; \mathrm{K}_{\mathrm{i}}: 1.90 \mu \mathrm{M}$ & Kar et al, $2020^{23}$ \\
\hline 17 & Eugenol & S & $\Delta \mathrm{G}:-7.3 \mathrm{kcal} / \mathrm{mol} ; \mathrm{K}_{\mathrm{i}}: 4.42 \mu \mathrm{M}$ & Kar et al, $2020^{23}$ \\
\hline 18 & Eugenol & MPro & $\Delta \mathrm{G}:-7.6 \mathrm{kcal} / \mathrm{mol} ; \mathrm{K}_{\mathrm{i}}: 2.67 \mu \mathrm{M}$ & Kar et al, $2020^{23}$ \\
\hline 19 & Stigmasterol & $\mathrm{S}$ & $\Delta \mathrm{G}:-7.2 \mathrm{kcal} / \mathrm{mol}$ & Kar et al, $2020^{24}$ \\
\hline 20 & Stigmasterol & MPro & $\Delta \mathrm{G}:-7.7 \mathrm{kcal} / \mathrm{mol}$; & Kar et al, $2020^{24}$ \\
\hline 21 & Stigmasterol & $\operatorname{RdRp}$ & $\Delta \mathrm{G}:-7.0 \mathrm{kcal} / \mathrm{mol} ;$ & Kar et al, $2020^{24}$ \\
\hline
\end{tabular}




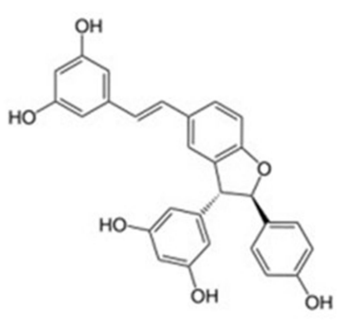

A Delta - viniferin (grapes, red wine)<smiles>COc1cc(C2Oc3cc([C@H]4Oc5cc(O)cc(O)c5C(=O)C4O)ccc3O[C@H]2CO)ccc1O</smiles>

C Silibinin (milk thistle)<smiles>O=C(OC1Cc2c(O)cc(O)cc2OC1c1cc(O)c(O)c(O)c1)c1cc(O)c(O)c(O)c1</smiles>

E EGCG (green tea)<smiles>CC(C)c1cc2c(c(O)c1O)C13CCCC(C)(C)C1CCOC23O</smiles>

G Carnosol (rosemary)<smiles>O=c1c(O)c(-c2cc(O)c(O)c(O)c2)oc2cc(O)cc(O)c12</smiles>

B Myricetin (tomatoes, oranges, berries and tea

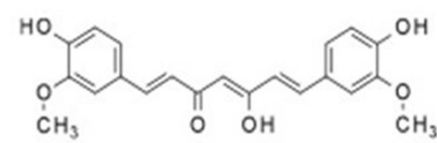

D Curcumin (turmeric)<smiles>O=c1cc(-c2ccc(O)c(O)c2)oc2cc(O)cc(O)c12</smiles>

F Luteolin (broccoli, green pepper, carrots)<smiles></smiles>

H Quercetin (red onions, apples, kale)

Figure 3 Nutraceuticals shown to be binding to target sites of SARS-CoV-2 are as follows: (A) $\delta$-viniferin binds to RdRP, MPro and human ACE2 receptor, (B) myricetin binds to $S$ protein, (C) silibinin binds to RdRp, (D) curcumin binds to MPro, NP, nsp I0, (E) EGCG binds to MPro, (F) luteolin binds to S protein, (G) carnosol binds to MPro, (H) quercetin binds to $S$ protein.

resorcinol moiety—seems to be a common feature in these nutraceuticals (Figure 3).

Khan et a ${ }^{19}$ docked 18 known natural antiviral compounds against seven SARS-CoV-2 proteins and compared them with remdesivir and chloroquine. Their modelling studies showed EGCG and curcumin to affect multiple targets of SARS-CoV-2. EGCG showed binding affinity towards main protease, spike protein, post fusion S2 protein, and nsp15 endoribonuclease. Curcumin, however, showed increased binding affinity towards the main protease and nsp15 endoribonuclease. Curcumin binding to NP and nsp10 was observed by Suravajhala et al. ${ }^{10}$
Joshi et $\mathrm{al}^{13}$ screened a custom-made library of more than 7000 natural molecules such as flavonoids, glucosinolates, terpenoids, alkaloids, and others against the MPro. MPro does not have a sequence homologous structure in humans and hence targeting this protease would be specific for the virus. Since coughing is a major symptom of COVID-19, Joshi et al also screened traditionally known antitussive medicines against various structural proteins of SARS-CoV-2. They followed this up by screening the hits against RdRp and ACE2 in order to find multi-target inhibitors. Multi-target inhibitors have the added advantage that they could be effective in all stages of the virus 
life cycle. EGCG is shown to reduce TMPRSS2 secretion. Clerodendrum species have been used as an age-old remedy for respiratory ailments. Hence, phytochemicals from 12 different species were assessed for their potential to bind to the coronavirus proteins, wherein stigmasterol was found to be a promising candidate. ${ }^{24}$

Silibinin not only acts as a direct inhibitor of viral proteins, but is also found to play a role in modifying the inflammatory response. Similarly, EGCG, has additional fat burning action (increasing fat oxidation), which prevents disease progression.

$\mathrm{Hu}$ et al, ${ }^{22}$ observed that flavonoids in general, showed higher affinity towards MPro compared to alkaloids, terpenes and saponins. They suggest that this may be owing to the phenolic hydroxyl group of the flavonoids which can interact more easily with the heteroatoms of the amino acids of MPro. They found rutin to be especially effective in binding to MPro. Buckwheat, apple and tea contain considerable amount of rutin and can be consumed in higher quantities to protect oneself from the infection. The screening study conducted by Fischer et $\mathrm{al},{ }^{25}$ revealed rhamnetin, found in Moringa oleifera plant, to show greater affinity for MPro. Rhamnetin is already commercially available. Rhamnetin is also structurally similar to quercetin. Myricitrin is a glycosylated analog of myricetin and is found in black grapes. Glycosylated flavonoids have an increased bioavailability compared to the aglycone forms. ${ }^{25}$ Myricitrin, myricetin, resveratrol, and $\delta$-viniferin, have been found to be potential anti-COVID-19 therapeutics.

Kar et $\mathrm{al}^{23}$ evaluated multiple phytochemicals and nutraceuticals for their potential to bind to either S, MPro or RdRp proteins. Post evaluation of in silico binding, these authors have also assessed the adherence of the selected ligands to the Lipinsky's rule of five. While eugenol was found to adhere to the Lipinsky's rule of five, mangiferin showed slight deviation. However, these deviations can be corrected through formulation innovations.

Octacosanol, cinametic acid, lauric acid, ascorbyl palmitate, and palmidrol are few of the nutraceuticals found to bind to the envelope protein. These can potentially disrupt the viroporin activity, and can provide relief from edema and inflammation, commonly observed in acute respiratory distress syndrome (ARDS) ${ }^{26}$

Sulforaphane is an isothiocyanate formed upon hydrolysis of glucosinolates found in cruciferous vegetables like broccoli and cabbage and can modulate levels of TMPRSS2 $2{ }^{27}$ It is also shown to upregulate Nrf2 thus enhancing the anti-inflammatory response of the body.
Hence, consumption of cruciferous vegetables may be helpful as a preventive strategy against SARS-CoV-2.

Given that these molecules target different viral proteins at different stages of viral replication, and a majority of them are common ingredients of the food chain (eg curcumin from turmeric, carnosol from rosemary, quercetin in apples, etc), it can be assumed that consumption of such foods may positively impact protection against SARS-CoV2 infection. However, supraphysiological dosing of nutraceuticals is a double-edged sword, with evidence on both sides - of effectiveness and toxicity. For example, the supraphysiological dosing of vitamins and nutrients (mainly flavonoids and omega-3 fatty acids) for treatment of brain injury is now well established with strong evidence backing their use. ${ }^{28}$ However, high doses of chlorogenic acid are known to increase plasma homocysteine levels. ${ }^{29}$ This kind of unexpected spinoff is more pronounced in the case of antioxidants, as they function as antioxidants at physiological dose, while occasionally at higher amounts a pro-oxidant activity is observed. Antioxidants by their very nature are "redox" agents, hence they have both antioxidant and pro-oxidant activities inherent in their structure. It is important to note that the physiological concentration of these nutraceuticals determines their function.

\section{Plant Protease Inhibitors as Potential Therapeutic Molecules Against SARS- CoV-2}

Viruses make use of proteases (generally host proteases) to gain entry into the host. Synthetic protease inhibitors have been widely used as treatment tools for a variety of viral diseases such as those caused by HIV, HCV, picornaviruses, SARS, rotavirus and others. ${ }^{30}$ They are also being investigated as potential treatment options for diabetes, cancer and inflammation. Viral protease inhibitors against HIV, HCV, picornaviruses, SARS have also been studied from bacterial and fungal origins. ${ }^{31}$

TMPRSS2 and furin are host serine proteases that facilitate the entry of SARS-CoV-2 into the host cell. TMPRSS2 is a trypsin like serine protease while furin is a subtilisin type serine protease. ${ }^{32}$ In addition, PLPro and the MPro which is a chymotrypsin-like cysteine protease, play important roles in viral replication. The epithelial cells of the respiratory tract themselves release proteases/protease inhibitors that help maintain homeostasis required for healthy lung functioning. ${ }^{27}$ The protease/protease inhibitors balance determines the extent of respiratory viral pathogenesis. A 
Table 3 Examples of Plant Protease Inhibitors (PPIs) as Potential Antiviral Agents

\begin{tabular}{|l|l|l|l|l|}
\hline S. No. & Plant Source-Scientific Name & Name of PPI & Type of Inhibitor & Enzyme Inhibited \\
\hline $\mathbf{I}$ & Vigna unguiculata (seeds) & BTCi & Bowman-Birk inhibitor & Trypsin, chymotrypsin \\
2 & Hordeum vulgare & HorvuZx (BSZx) & Serpin & Trypsin, chymotrypsin \\
& CI-I & Trypsin, chymotrypsin, subtilisin \\
3 & Cicer arietenum & SKTI & Kunitz & Trypsin \\
4 & Glycine max & BBI & Kunitz & Trypsin, chymotrypsin \\
& & Tamarind kunitz I & Kowman-Birk inhibitor & Trypsin \\
5 & Tamarindus indica & BI-I & Bowman-Birk inhibitor & Trypsin, chymotrypsin, papain \\
6 & Ananus comosus & CMTI-V & Potato type I & Trypsin \\
7 & Cucurbita maxima & TI-II & Potato type II & Trypsin, chymotrypsin, subtilisin \\
8 & Solanum lycopersicum & Cabbage TI & Mustard type PI & Trypsin \\
9 & Brassica oleracea & BWI-I & Potato type I & Trypsin, chymotrypsin, subtilisin \\
10 & Fagopyrum esculentum (seeds) & Moringa protease I & Kunitz & Trypsin, chymotrypsin, papain \\
\hline
\end{tabular}

shift towards more proteases can increase viral pathogenesis while the reverse may help protect against it.

Animal studies by Deng et $\mathrm{al}^{33}$ have shown that coronaviruses can gain quick resistance to 3CLPro inhibitors but this resistance comes at the fitness cost of the virus not being able to replicate fast enough thereby reducing infectivity. TMPRSS2 is a host secreted type 2 transmembrane serine protease and is shown to be sensitive to antiproteases in the midst of an infection. ${ }^{22}$ Therefore, protease inhibitors or antiproteases against these protease enzymes can be explored as potential therapeutic molecules.

The reviews by Hellinger and Gruber $^{34}$ as well as Srikanth and $\mathrm{Chen}^{35}$ describe a number of plant protease inhibitors, some of which have been collated in Table 3 . This could be a good starting point to start assessing these molecules for their effectiveness against the SARS-CoV-2 virus 3CLPro and papain-like proteases.

Although the main function of antiproteases is inhibiting or deactivating proteases, newer research is identifying more roles for them in controlling excessive inflammation and microbial infection. ${ }^{27}$ Hence identifying multifunctional plant protease inhibitors can allow multistep protection in coronavirus infection.

\section{Immunomodulatory Effects and Inflammatory Responses Brought About by the SARS-CoV-2 Virus}

The Immune System-Natural Defense Mechanism

During viral infection, the host cells recognize an invading virus through the pathogen-associated molecular patterns (PAMPs). This recognition further activates a series of cell signaling pathways through the pattern recognition receptors (PRRs). The toll-like receptors (TLRs), particularly TLR3 and TLR7 (endosomal receptors) and TLR8, recognize single-stranded RNA while other TLRs recognize the different viral components and set off the cellular signaling pathways. This leads to the production of proinflammatory cytokines (IL- 6 , TNF- $\alpha$, type-I interferons (IFNs) etc) (Figure 4) and certain chemokines which further triggers the immune responses by the various immune cells (such as the antigen presenting cells, APCs). The release of the cytokines and chemokines is the starting point for the downstream effects such as inflammatory responses, apoptosis or pyroptosis, and the activation of the adaptive immune response. Type-I IFN pathway plays a central role in mediating innate immune responses to viral infections.

The type-I IFNs activate the JAK-STAT pathway and the phosphorylation of the STAT1and STAT2 causes the transcription of IFN-stimulated genes (ISGs) to further reduce viral replication and thereby reduce the viral load in the system. ${ }^{1}$ The release of NF- $\mathrm{KB}$ transcription factors occurs downstream of TLRs activation and causes the release of pro-inflammatory cytokines.

The mitogen-activated protein kinases (MAPKs) pathway also gets activated during SARS-CoV infection. SARS-CoV also distinctly enhances the NLRP3 inflammasome pathway leading to a profound expression of proinflammatory cytokines and ROS.

The adaptive immune system is activated by the phagocytes that present the antigen to the $\mathrm{CD} 4^{+} \mathrm{T}$-helper cells which fight against the virus by developing into Th1 cells. The APCs can also activate $\mathrm{CD}^{+} \mathrm{T}$ cells which further exhibit their cytotoxic effects along with natural killer 


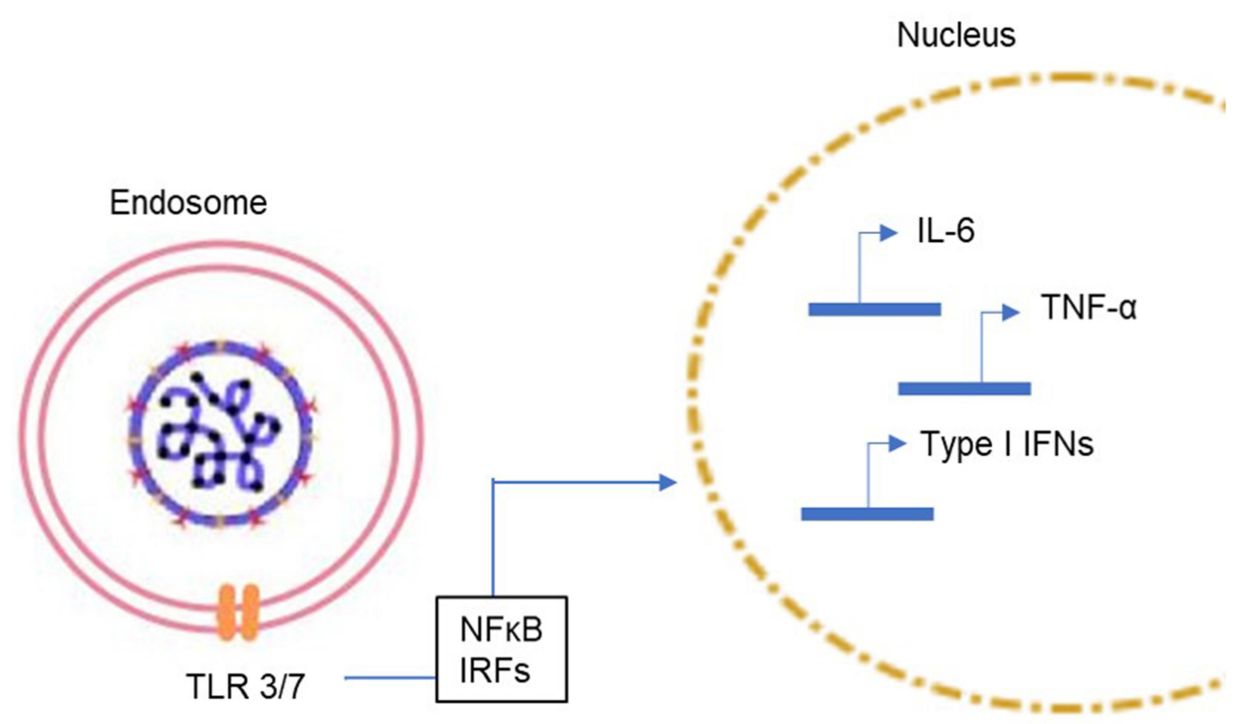

Figure 4 Signal cascade following the virus entry into the host cell. Viral entry results in the activation of the toll-like receptors (TLRs) present in the endosome and subsequent activation of the innate immune system through the NFKB transcription factor and interferon-regulatory factors (IRFs) which enter the nucleus and upregulate the expression of cytokines (IL-6, TNF $\alpha$ and type I interferons, etc).
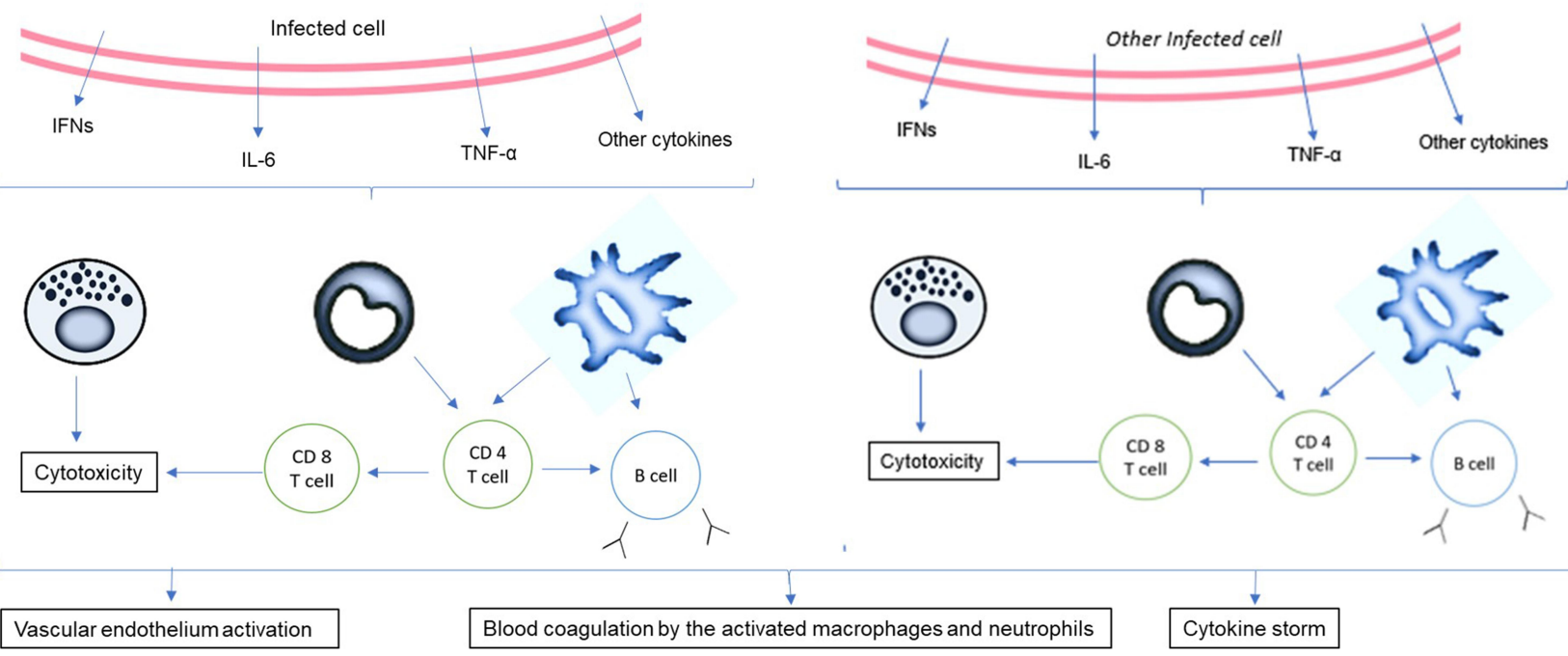

Vascular endothelium activation

Blood coagulation by the activated macrophages and neutrophils

Cytokine storm

Figure 5 Activation of cytokines post infection. The release of the virions and the subsequent spread of the infection to other cells leads to the production of several cytokines that activate the adaptive immune system. High viral titer leads to activation of the vascular endothelium and blood coagulation, especially in those suffering from comorbidities.

(NK) cells. The $\mathrm{CD} 4^{+}$cells also stimulate the $\mathrm{CD} 8^{+}$cells through co-stimulatory signals. The T cells further activate the $\mathrm{B}$ cells leading to antibody production (specifically $\operatorname{IgM}$ and $\operatorname{IgG}$ ) (Figure 5).

\section{Immunomodulatory and Inflammatory Responses Triggered by SARS-CoV-2}

At the onset of the infection cytokines play an important role in recruiting other phagocytes at the site of infection and eliciting immune response. Increase in viral load and evasion of the innate immune system by the virus causes a cytokine storm viz a marked increase in the levels of pro-inflammatory cytokines through various cellular pathways triggering inflammation, which contributes to morbidity and mortality. It has been reported that the cytokine storm aggravates the disease resulting in ARDS, a characteristic condition exhibited by critically ill patients. 
The virus has developed several strategies to evade the human defense system. It avoids the immune system by forming double vesicles that escape detection through PRRs. Furthermore, the viral particles are able to inhibit the STAT family transcription factors and suppress the expression of type-I IFNs. ${ }^{36}$ The nsps function to alter the structure of the virus to mimic the host cell components and thereby evade detection by the host immune system. ${ }^{1}$

Lymphopenia has also been cited as a cause for exacerbation of adverse effects of the disease. ${ }^{37}$ The low count of T cells results are not only due to the viral load, but also due to the cytokine storm. Previously, it was observed in SARS$\mathrm{CoV}$ infected individuals that there was an imbalance in the $\mathrm{CD}^{+}$and $\mathrm{CD}^{+}$ratio with a significant decrease in the $\mathrm{CD}^{+}$count compared to $\mathrm{CD} 8^{+}$cell count. ${ }^{38,39}$ Ageing, by itself results in similar disruption of $\mathrm{CD} 4^{+} / \mathrm{CD} 8^{+}$ratios, which in turn may be responsible for the increased susceptibility of the aged to SARS- CoV-2 infection. The cytokine storm and the immune dysregulation renders an individual with other comorbidities more susceptible to the disease. Hence, it is essential to build or enhance immunity not only to prevent infection, but also to prevent the acute stage of the disease once infected.

\section{Interventions to Regulate Immune Response in COVID-I 9 Patients}

Several nutraceuticals and natural compounds are known to have antiviral and immunomodulatory properties. Some of these compounds exhibit their functions by counteracting inflammation and ameliorating the ROS. Some of the strategies used in the past to counteract SARS-CoV infection were downregulation of MAPK pathway, reduction of NLRP3 inflammasome effects and inhibition of NF- $\mathrm{KB}$ while targeting a decrease in the pro-inflammatory cytokines, especially IL- $6 .^{40,41}$

Over expression of IL-6 causes enhanced expression of STAT3. Studies suggest that the use of inhibitors of the JAK-STAT pathway can be potential therapeutic strategy. Recent studies have discovered the positive effect of silibinin, a flavolignan obtained from milk thistle and apigenin obtained from dried parsley in inhibiting cytokine storm by preventing STAT3 activation and its nuclear translocation. ${ }^{21}$ Some of the nutraceuticals that can downregulate these different pathways are mentioned in Table 4. Immunity boosters that restore the adaptive immunity are also potential targets. Jacalin (a lectin from jackfruits) was shown to increase the levels of $\mathrm{CD}^{+}$cells and thus restore the $\mathrm{CD}^{+}$and $\mathrm{CD} 8^{+}$cell ratio in an immunocompromised individual. Thus, it could be used to address the issue of lymphopenia and further enhance immunity. ${ }^{42}$

\section{COVID-I 9 and Metabolic Diseases}

A large number of people suffering from various metabolic diseases, such as hypertension, obesity, cardiovascular diseases, type 2 diabetes, etc are more susceptible to infection from the SARS-CoV-2 virus. ${ }^{60}$ The immunomodulatory effects due to the infection not only contribute to the severity of the metabolic diseases, but also exacerbate the adverse effects of infection.

An understanding of the onset and subsequent severity of the viral infection along with other comorbidities will help in identifying suitable nutraceuticals that can act on relevant pathways to ameliorate the conditions. Figure 6 succinctly delineates the cross-talk between the immune and metabolic pathways.

\section{Noncommunicable Diseases}

Two major noncommunicable diseases, obesity and type-2 diabetes, are characterized by the dysregulation of PPAR $\gamma$ and IRS-1 expression occurring through the influence of IL-1 and TNF- $\alpha \cdot{ }^{61-63}$ Downregulation of ppargc1a further leads to pulmonary damage of the alveolar macrophages and epithelial cells, a characteristic symptom in the critically-ill COVID-19 patients. Furthermore, in addition to the alveolar epithelial cells, adipose and pancreatic tissues too express ACE2 and are thus prone to SARS-CoV-2 attack. ${ }^{64}$ Diabetic patients are often treated with ACE inhibitors, which results in higher expression of ACE2 ${ }^{65}$ Impaired glucose metabolism in diabetic patients results in dysregulated $\mathrm{T}$ cell activation and causes oxidative stress, further compromising the immune system of the infected individual. ${ }^{66}$

\section{Dyslipidemia}

A disruption in lipid homeostasis leads to dyslipidemia, characterized by elevated total cholesterol, triglycerides and low-density lipoprotein (LDL) with low levels of high-density lipoprotein (HDL). ${ }^{67}$ IL-6 leads to vascular cell damage by enhancing the permeability of oxidized LDL, resulting in lung injury. During the SARS-CoV-2 infection, the cytokine storm increases LDL oxidation 
Table 4 List of Nutraceuticals Exhibiting Immunomodulatory and Anti-inflammatory Effects

\begin{tabular}{|c|c|c|c|c|}
\hline S. No. & Nutraceutical & Common Sources & Action & $\begin{array}{l}\text { Study, Year, } \\
\text { Reference }\end{array}$ \\
\hline I & Curcumin & Turmeric & $\begin{array}{l}\text { - Inhibits NF-kB pathway } \\
\text { - Inhibits p38 MAPK pathway } \\
\text { - Downregulates STAT3 of the JAK/STAT pathway }\end{array}$ & $\begin{array}{l}\text { Al Mijan and Lim, } \\
2018^{43}\end{array}$ \\
\hline 2 & Epicatechins & $\begin{array}{l}\text { Tea leaves, apples, cocoa, } \\
\text { grapes }\end{array}$ & Downregulates STAT3 of the JAK/STAT pathway & Yang et al, $2015^{44}$ \\
\hline 3 & $\begin{array}{l}\text { Quercetin and } \\
\text { dihydroquercetin }\end{array}$ & $\begin{array}{l}\text { Onions, apples, citrus } \\
\text { fruits, honey }\end{array}$ & $\begin{array}{l}\text { - Downregulates STAT3 of the JAK/STAT pathway } \\
\text { - Inhibits NF-KB pathway } \\
\text { - Reduces expression of pro-inflammatory cyto- } \\
\text { kines (IL-6) }\end{array}$ & Khan et al, $2016^{45}$ \\
\hline 4 & Hesperetin & Lemons, oranges & Downregulates STAT3 of the JAK/STAT pathway & Choi et al, $2008^{46}$ \\
\hline 5 & Kaempferol & $\begin{array}{l}\text { Apples, grapes, tomato, } \\
\text { green tea, onions, } \\
\text { cucumbers }\end{array}$ & $\begin{array}{l}\text { - Downregulates JAK/STAT pathway } \\
\text { - Inhibits NF-KB pathway } \\
\text { - Inhibits MAPK pathway } \\
\text { - Reduces expression of pro-inflammatory cyto- } \\
\text { kines (IL-6) }\end{array}$ & $\begin{array}{l}\text { Hämäläinen et al, } \\
2007^{47}\end{array}$ \\
\hline 6 & Emodin & Rhubarb & $\begin{array}{l}\text { - Downregulates STAT3 of the JAK/STAT pathway } \\
\text { - Inhibits NF-KB pathway } \\
\text { - Inhibits MAPK pathway } \\
\text { Reduces expression of pro-inflammatory cyto- } \\
\text { kines (IL-6) }\end{array}$ & $\begin{array}{l}\text { Hsu and Chung, } \\
2012^{48}\end{array}$ \\
\hline 7 & Ursolic acid & $\begin{array}{l}\text { Apples, basil, oregano, } \\
\text { thyme, prunes }\end{array}$ & $\begin{array}{l}\text { - Downregulates STAT3 of the JAK/STAT pathway } \\
\text { - Inhibits NF-KB pathway } \\
\text { - Reduces expression of pro-inflammatory cyto- } \\
\text { kines (IL-6) }\end{array}$ & $\begin{array}{l}\text { Kashyap et al, } \\
2016^{49}\end{array}$ \\
\hline 8 & Vitamin E & $\begin{array}{l}\text { Nuts (like almonds and } \\
\text { peanuts), seeds } \\
\text { (sunflower seeds), } \\
\text { vegetable oil and green } \\
\text { leafy vegetables }\end{array}$ & $\begin{array}{l}\text { - Inhibits NF-kB pathway } \\
\text { - Reduces expression of pro-inflammatory cyto- } \\
\text { kines (IL-6) }\end{array}$ & $\begin{array}{l}\text { Huang et al, } \\
2004^{50}\end{array}$ \\
\hline 9 & Vitamin C & $\begin{array}{l}\text { Guava, citrus fruits, } \\
\text { tomatoes }\end{array}$ & Inhibits NF-kB pathway & $\begin{array}{l}\text { Huang et al, } \\
2004^{50}\end{array}$ \\
\hline 10 & Vitamin B6 & $\begin{array}{l}\text { Whole grain cereals, eggs, } \\
\text { soybeans, fish and meat } \\
\text { products }\end{array}$ & $\begin{array}{l}\text { - Inhibits NF-KB pathway } \\
\text { - Inhibits activation of NLRP3 inflammasome) }\end{array}$ & $\begin{array}{l}\text { Yanaka et al, } \\
2005^{51}\end{array}$ \\
\hline II & Resveratrol & Grapes, peanuts & Inhibits NF-kB pathway & $\begin{array}{l}\text { Huang et al, } \\
2004^{50}\end{array}$ \\
\hline 12 & Theaflavins & Tea leaves & $\begin{array}{l}\text { - Inhibits NF-KB pathway } \\
\text { - Reduces expression of pro-inflammatory cyto- } \\
\text { kines (IL-6) }\end{array}$ & $\begin{array}{l}\text { Huang et al, } \\
2004^{50}\end{array}$ \\
\hline 13 & Genistein & Soybeans & $\begin{array}{l}\text { - Inhibits NF-kB pathway } \\
\text { - Reduces expression of pro-inflammatory cyto- } \\
\text { kines (IL-6) }\end{array}$ & $\begin{array}{l}\text { Huang et al, } \\
2004^{50}\end{array}$ \\
\hline
\end{tabular}

(Continued) 
Table 4 (Continued).

\begin{tabular}{|c|c|c|c|c|}
\hline S. No. & Nutraceutical & Common Sources & Action & $\begin{array}{l}\text { Study, Year, } \\
\text { Reference }\end{array}$ \\
\hline 14 & Chlorogenic acid & $\begin{array}{l}\text { Coffee, tea, apples, } \\
\text { carrots }\end{array}$ & $\begin{array}{l}\text { - Inhibits NF-kB pathway } \\
\text { - Reduces expression of pro-inflammatory cyto- } \\
\text { kines (IL-6) } \\
\text { - Inhibits activation of NLRP3 inflammasome }\end{array}$ & Zhang et al, $2018^{52}$ \\
\hline 15 & $\begin{array}{l}\text { Zingerone and } 12- \\
\text { dehydrogingerdione }\end{array}$ & Ginger & $\begin{array}{l}\text { - Inhibits NF-kB pathway } \\
\text { - Reduces expression of pro-inflammatory cyto- } \\
\text { kines (IL-6) }\end{array}$ & $\begin{array}{l}\text { Dos Tramontins et } \\
\text { al, } 2020^{53}\end{array}$ \\
\hline 16 & Sesamol & Sesame & $\begin{array}{l}\text { - Inhibits NF-KB pathway } \\
\text { - Inhibits MAPK pathway } \\
\text { - Reduces expression of pro-inflammatory } \\
\text { cytokines }\end{array}$ & $\begin{array}{l}\text { Majdalawieh and } \\
\text { Mansour, } 2019^{54}\end{array}$ \\
\hline 17 & Alliin & Garlic & $\begin{array}{l}\text { - Inhibits MAPK pathway } \\
\text { - Reduces expression of pro-inflammatory cyto- } \\
\text { kines (IL-6) }\end{array}$ & $\begin{array}{l}\text { Sánchez-sánchez et } \\
\text { al, } 2020^{55}\end{array}$ \\
\hline 18 & Apigenin & $\begin{array}{l}\text { Grapefruit, onion, } \\
\text { oranges, chamomile, } \\
\text { parsley }\end{array}$ & $\begin{array}{l}\text { - Inhibits NF-kB pathway and STAT3 } \\
\text { - Reduces expression of pro-inflammatory cyto- } \\
\text { kines (IL-6) }\end{array}$ & $\begin{array}{l}\text { Nicholas et al, } \\
2007^{56}\end{array}$ \\
\hline 19 & Luteolin & $\begin{array}{l}\text { Broccoli, carrot, thyme, } \\
\text { chamomile }\end{array}$ & $\begin{array}{l}\text { - Inhibits NF-KB pathway } \\
\text { - Inhibits MAPK pathway }\end{array}$ & $\begin{array}{l}\text { Nicholas et al, } \\
2007^{56}\end{array}$ \\
\hline 20 & L-carnitine & $\begin{array}{l}\text { Dairy products (whey } \\
\text { portion), meat and fish }\end{array}$ & $\begin{array}{l}\text { - Inhibits NF-KB pathway } \\
\text { - Reduces expression of CRP and pro-inflammatory } \\
\text { cytokines (IL-6) }\end{array}$ & $\begin{array}{l}\text { Haghighatdoost et } \\
\text { al, } 2019^{57}\end{array}$ \\
\hline 21 & Berberine & Turmeric & $\begin{array}{l}\text { - Inhibits NF-KB pathway } \\
\text { - Inhibits MAPK pathway } \\
\text { - Reduces expression of pro-inflammatory } \\
\text { cytokines }\end{array}$ & $\begin{array}{l}\text { Marín-Aguilar et al, } \\
2017^{58}\end{array}$ \\
\hline 22 & Taxifolin & Milk thistle, onion & $\begin{array}{l}\text { - Downregulates STAT3 of the JAK/STAT pathway } \\
\text { - Inhibits NF-kB pathway }\end{array}$ & $\begin{array}{l}\text { Sunil and } \mathrm{Xu} \text {, } \\
2019^{59}\end{array}$ \\
\hline
\end{tabular}

and reduces the levels of HDL-c and PON1, leading to dyslipidemia and exacerbation of other metabolic diseases. $^{68}$

In accordance with these observations, the lipid profile of the epithelial cells in patients suffering from SARS-CoV showed high concentrations of fatty acids and phospholipids and this condition has been considered to be conducive for viral replication. ${ }^{64}$ Furthermore, SARS-CoV-2 entry results in higher levels of angiotensin II which can lead to upregulation of IL-6, CAMs and several other cytokines and chemokines via the NF- $\mathrm{B}$ pathway causing vascular diseases. $^{69}$

\section{Suitable Interventions to Address the Metabolic Diseases}

In order to reduce this influence of the metabolic diseases and COVID-19 on one another, the target nodes in focus could be, (a) AMPK pathway (the upregulation of AMPK pathway downregulates inflammation and exhibits hypolipidemic effects), (b) specialized pro-resolving mediators, SPMs (agonists of PPAR $\gamma$ as their activation would target lipid metabolism as well as work as potential SPMs to restore homeostasis in a COVID-19 patient), (c) lipid oxidation (fatty acid oxidation ensures minimization of lipotoxicity as well as reduces damages caused to cells by dyslipidemia). 


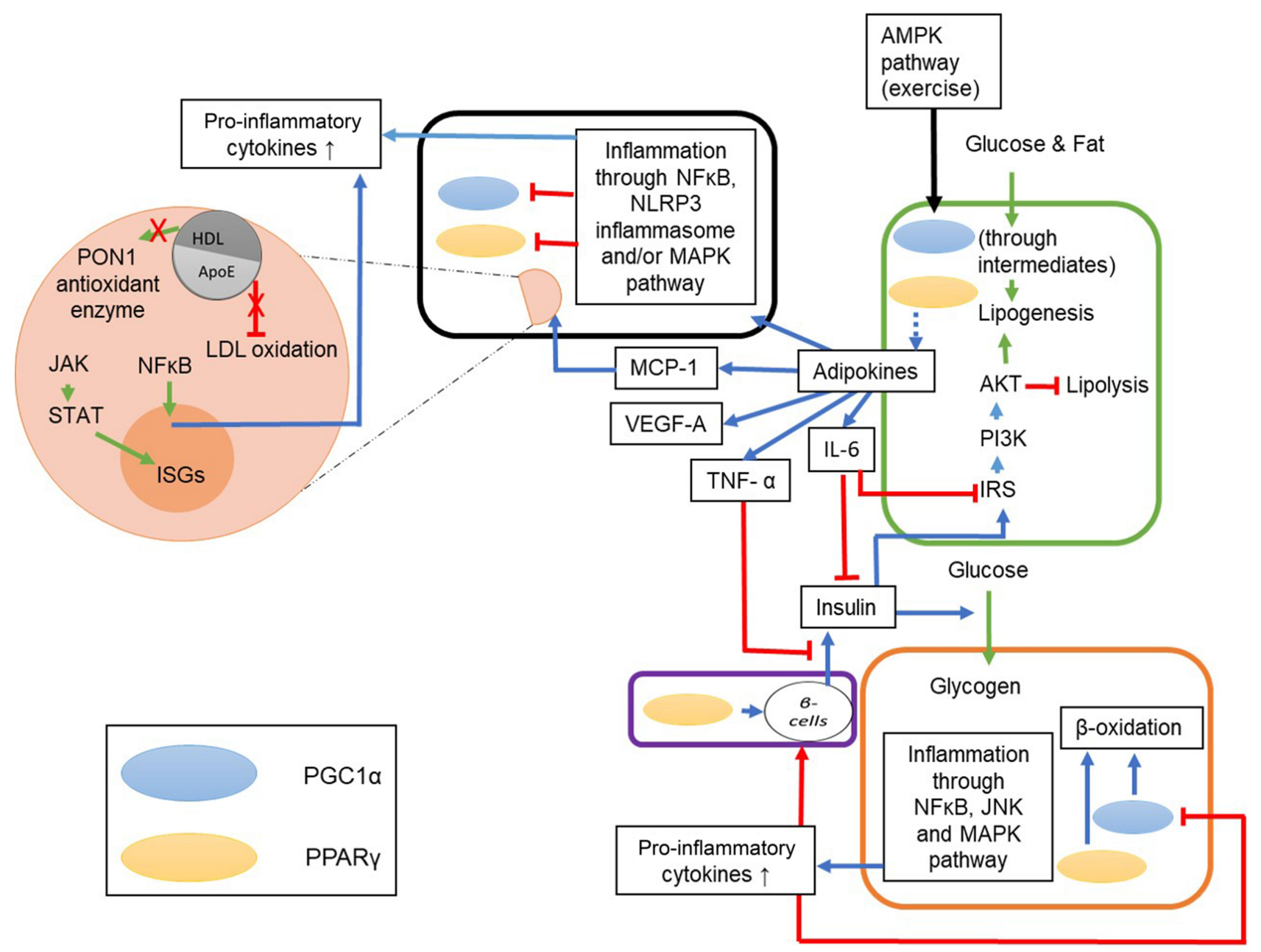

Figure 6 The interlinked immune signaling pathways and metabolism. The green box represents adipocytes, orange box represents hepatocytes, and purple box represents pancreatic cells. The green arrows represent the metabolic process and the cellular machinery process, the blue arrows represent the immune response elicited by molecules or factors and the red lines represent inhibition. The PPARs and PGCl $\alpha$ present in the cells influence adipokines and $\beta$-oxidation; the blue dotted line represent regulation (either up- or downregulation). The immune signaling involved during the metabolism process includes release of pro-inflammatory cytokines by the adipocytes (IL-6, TNF $\alpha$, MCP-I, VEGF-A, etc), inhibition of lipolysis via activation of PI3K/Akt pathway, inhibition of insulin function by the adipokines (IL-6 and TNF- $\alpha$ ) and activation of AMPK pathway, which upregulates PGCl $\alpha$ further enhancing $\beta$-oxidation. Dyslipidemia results in inflammation in the hepatocytes through the JNK and MAPK pathways which release pro-inflammatory cytokines that can inhibit $\beta$-oxidation and expression of $\beta$-cells in the pancreas. The black box represents a SARS-CoV- 2 infected cell where the MCP-I causes macrophage infiltration (orange circle) at the site of infection resulting in a decrease in HDL levels, loss of PONI enzyme activity and increase in oxidization of LDL. It also results in activation of inflammatory pathways (JAK/STAT and NF- $K B$ ) and hence the cytokine storm.

Nutraceuticals used in the management of metabolic disorders are suitable interventions to alleviate the comorbidities in a COVID-19 patient. These are listed in Tables 5 and 6.

\section{Probiotics and Prebiotics}

Probiotics or the gut microbiota play an important role in curbing inflammatory response and the associated metabolic diseases. Strains of Bifidobacterium and Lactobacillus species are the common probiotics found naturally as well as available commercially. The braingut axis facilitates the expression of anti-inflammatory cytokines through inhibition of TLRs. ${ }^{113}$ The intestine has a high expression of ACE2 and is thus susceptible to SARS-CoV attack, evident from the GI symptoms exhibited in a few patients. ${ }^{114}$ Therefore, supplementing a patient with probiotics is a therapeutic approach to control the spread of the infection and can also act as a prophylactic treatment. The presence of microorganisms in the lungs has also been reported, with Bacteroidetes, Firmicutes, and Proteobacteria being the three main phyla characterized. ${ }^{114}$ Similar to the brain-gut axis, there exists the gut-lung axis - a link between the gut microbiota and the lungs acting through blood vessels, whereby the metabolites from the gut has an influence on the functioning of the lungs, acting via Nod-2 and GM- 
Table 5 Natural Food Sources Exhibiting Anti-obesity, Antidiabetic and Hypolipidemic Effects

\begin{tabular}{|c|c|c|c|c|c|}
\hline S. No. & Source & $\begin{array}{l}\text { Bioactive } \\
\text { Molecules }\end{array}$ & Effects & Studies Undertaken & $\begin{array}{l}\text { Study, } \\
\text { Year, } \\
\text { Reference }\end{array}$ \\
\hline \multirow[t]{2}{*}{1} & \multirow[t]{2}{*}{$\begin{array}{l}\text { Bitter gourd } \\
\text { (Momordica } \\
\text { charantia) }\end{array}$} & \multirow{2}{*}{$\begin{array}{l}\text { Charantin } \\
\text { Vicine } \\
\text { Cucurbitane } \\
\text { Momordicin II } \\
\text { Kuguaglycoside G } \\
\alpha \text {-eleostearic acid }\end{array}$} & \multirow{2}{*}{$\begin{array}{l}\text { Hypolipidemic function: } \\
\text { - Increases HDL-c levels. } \\
\text { - Enhances expression of } \\
\text { PGCl } \alpha \\
\text { - Enhances PPAR } \alpha \text { and } \\
\text { PPAR } \gamma \text { via AMPK path- } \\
\text { way } \\
\text { Anti-hyperglycemic func- } \\
\text { tion: } \\
\text { Improves insulin } \\
\text { sensitivity }\end{array}$} & $\begin{array}{l}\text { Mice were administered bitter gourd extract } \\
(250,500 \text { and } 1000 \mathrm{mg} / \mathrm{kg} \text { of body weight) and } \\
\text { the mRNA expression of PPARs and their target } \\
\text { genes were studied. }\end{array}$ & $\begin{array}{l}\text { Chao et al, } \\
2011^{70}\end{array}$ \\
\hline & & & & $\begin{array}{l}\text { Rats fed high fat diet extract for } 10 \text { weeks were } \\
\text { supplemented with bitter gourd for two weeks. }\end{array}$ & $\begin{array}{l}\text { Sridhar et al, } \\
2008^{71}\end{array}$ \\
\hline \multirow[t]{2}{*}{2} & \multirow[t]{2}{*}{$\begin{array}{l}\text { Ginger } \\
\text { (Zingiber } \\
\text { officinale) }\end{array}$} & \multirow{2}{*}{$\begin{array}{l}\text { Zingerone } \\
\text { Zingiberene } \\
\text { Gingerols } \\
\text { 6-shogaol } \\
\text { Gingerenone A }\end{array}$} & \multirow{2}{*}{$\begin{array}{l}\text { Hypolipidemic function: } \\
\text { - Enhances } \beta \text {-oxidation } \\
\text { - Upregulates PGCI } \alpha \\
\text { - Increases HDL-c levels } \\
\text { - Activates PPARs } \\
\text { Anti-hyperglycemic func- } \\
\text { tion: } \\
\text { improves insulin } \\
\text { sensitivity }\end{array}$} & $\begin{array}{l}\text { In vivo and in vitro studies were carried out on } \\
\text { obese mice to observe the effects of ginger } \\
\text { extracts on obesity and its mechanism of action }\end{array}$ & $\begin{array}{l}\text { Misawa et al } \\
2015^{72}\end{array}$ \\
\hline & & & & $\begin{array}{l}\text { A meta-analysis was performed to study the } \\
\text { effects of ginger on lipid profile in obesity. }\end{array}$ & $\begin{array}{l}\text { Maharlouei } \\
\text { et al, } 2019^{73}\end{array}$ \\
\hline \multirow[t]{3}{*}{3} & \multirow{3}{*}{$\begin{array}{l}\text { Turmeric } \\
\text { (Curcuma } \\
\text { longa) }\end{array}$} & \multirow[t]{3}{*}{$\begin{array}{l}\text { Curcumin } \\
\text { Curcuminoids }\end{array}$} & \multirow{3}{*}{$\begin{array}{l}\text { Hypolipidemic function: } \\
\text { - Upregulates PGCl } \alpha \\
\text { - Increases HDL-c levels. } \\
\text { Restoring homeostasis: } \\
\text { Activates AMPK/PPAR } \\
\text { pathway }\end{array}$} & $\begin{array}{l}\text { Mice were fed high fat diet along with curcumin } \\
\text { ( } 4 \mathrm{~g} / \mathrm{kg} \text { body weight). }\end{array}$ & $\begin{array}{l}\text { Shao et al, } \\
2012^{74}\end{array}$ \\
\hline & & & & $\begin{array}{l}\text { Subjects with T2D were supplemented with } \\
\text { curcuminoids ( } 1000 \mathrm{mg} / \text { day) with piperine ( } 10 \\
\mathrm{mg} / \text { day) for } 12 \text { weeks. }\end{array}$ & $\begin{array}{l}\text { Panahi et al, } \\
2017^{75}\end{array}$ \\
\hline & & & & $\begin{array}{l}\text { In vitro studies were carried out to evaluate the } \\
\text { effects of curcumin on adipocytes }\end{array}$ & $\begin{array}{l}\text { Lone et al, } \\
2016^{76}\end{array}$ \\
\hline \multirow[t]{2}{*}{4} & \multirow[t]{2}{*}{ Green tea } & \multirow[t]{2}{*}{$\begin{array}{l}\text { Epigallocatechin-3- } \\
\text { gallate (EGCG) }\end{array}$} & \multirow{2}{*}{$\begin{array}{l}\text { Hypolipidemic function: } \\
\text { - Enhances } \beta \text {-oxidation. } \\
\text { - Activates AMPK/PPAR } \\
\text { pathway. } \\
\text { - Restores PONI activity. } \\
\text { - Reduces levels of LDL, } \\
\text { cholesterol and } \\
\text { triglycerides. } \\
\text { - Increase in HDL levels } \\
\text { Anti-hyperglycemic func- } \\
\text { tion: } \\
\text { Improves insulin } \\
\text { sensitivity }\end{array}$} & $\begin{array}{l}\text { Male SD rats were studied under normal, } \\
\text { hyperglycemic and hypercholesterolemic } \\
\text { conditions and were fed diet with green tea } \\
\text { powder (functional food) and green tea extracts } \\
\text { (nutraceutical) }\end{array}$ & $\begin{array}{l}\text { Yousaf et al, } \\
2014^{77}\end{array}$ \\
\hline & & & & $\begin{array}{l}\text { Subjects were given catechin supplementation in } \\
\text { the form of decaffeinated green tea extracts } \\
\text { (equivalent to four cups of green tea) }\end{array}$ & $\begin{array}{l}\text { Hsu et al, } \\
2007^{78}\end{array}$ \\
\hline 5 & Capsicum & $\begin{array}{l}\text { Capsaicin } \\
\text { Dihydrocapsaicin } \\
\text { Homocapsaicin } \\
\text { Nordihydrocapsaicin }\end{array}$ & $\begin{array}{l}\text { Hypolipidemic function: } \\
\text { upregulates PPAR } \alpha\end{array}$ & $\begin{array}{l}\text { In vitro studies of the effect of capsaicin on } \\
\text { adipocytes were carried out. }\end{array}$ & $\begin{array}{l}\text { Kang et al, } \\
2007^{79}\end{array}$ \\
\hline
\end{tabular}

(Continued) 
Table 5 (Continued).

\begin{tabular}{|c|c|c|c|c|c|}
\hline S. No. & Source & $\begin{array}{l}\text { Bioactive } \\
\text { Molecules }\end{array}$ & Effects & Studies Undertaken & $\begin{array}{l}\text { Study, } \\
\text { Year, } \\
\text { Reference }\end{array}$ \\
\hline \multirow[t]{2}{*}{6} & \multirow[t]{2}{*}{$\begin{array}{l}\text { Drumstick } \\
\text { (Moringa } \\
\text { oleifera) }\end{array}$} & \multirow{2}{*}{$\begin{array}{l}\beta \text {-sitosterol } \\
\text { Quercetin } \\
\text { Chlorogenic acid } \\
\text { Benzylamine }\end{array}$} & \multirow{2}{*}{$\begin{array}{l}\text { Hypolipidemic function: } \\
\text { decreases total cholesterol, } \\
\text { LDL-c levels and increases } \\
\text { the HDL-c/non-HDL-c } \\
\text { levels. }\end{array}$} & $\begin{array}{l}\text { Rats were fed various doses of Moringa oleifera } \\
\text { extracts }(150,300 \text { and } 600 \mathrm{mg} / \mathrm{kg} \text { ) along with } \\
\text { high fat diet. }\end{array}$ & $\begin{array}{l}\text { Jain et al, } \\
2010^{80}\end{array}$ \\
\hline & & & & $\begin{array}{l}\text { Type } 2 \text { diabetic patients received a treatment of } \\
\text { Moringa leaves powder }(8 \mathrm{~g}) \text { for } 40 \text { days. }\end{array}$ & $\begin{array}{l}\text { Kumari } \\
2010^{81}\end{array}$ \\
\hline 7 & Soybean & $\begin{array}{l}\beta \text {-sitosterol } \\
\text { Quercetin } \\
\text { Chlorogenic acid } \\
\text { Benzylamine } \\
\text { Genistein } \\
\text { Daidzein } \\
\text { Glycitein }\end{array}$ & $\begin{array}{l}\text { Hypolipidemic function: } \\
\text { - Decreases the LDL-c } \\
\text { levels. } \\
\text { - Reduces the LDL-c to } \\
\text { HDL-c ratio. }\end{array}$ & $\begin{array}{l}\text { - A double-blind randomized study on adults } \\
\text { with type } 2 \text { diabetes where the study group } \\
\text { were fed soy protein isolates ( } 80 \mathrm{mg} / \mathrm{d} \text { of } \\
\text { aglycone isoflavones). } \\
\text { - Isoflavone composition was } 65 \% \text { genistein, } 31 \% \\
\text { daidzein, and } 4 \% \text { glycitein. }\end{array}$ & $\begin{array}{l}\text { Pipe et al, } \\
2009^{82}\end{array}$ \\
\hline 8 & Rosemary & $\begin{array}{l}\text { Rosmarinic acid } \\
\text { Carnosic acid }\end{array}$ & $\begin{array}{l}\text { Hypolipidemic function: } \\
\text { - Increases HDL-c levels } \\
\text { - Reduces total cholesterol } \\
\text { and LDL-c levels. } \\
\text { Antidiabetic function: } \\
\text { Stimulates insulin } \\
\text { secretion }\end{array}$ & $\begin{array}{l}\text { Adults were fed } 10 \mathrm{~g} \text { of rosemary leaves powder } \\
\text { each day for four weeks. }\end{array}$ & $\begin{array}{l}\text { Labban et al, } \\
2014^{83}\end{array}$ \\
\hline \multirow[t]{2}{*}{9} & \multirow[t]{2}{*}{ Pomegranate } & \multirow{2}{*}{$\begin{array}{l}\text { Ellagic acid } \\
\text { Gallic acid } \\
\text { Quercetin }\end{array}$} & \multirow{2}{*}{$\begin{array}{l}\text { Hypolipidemic function: } \\
\text { Reduces TC, TG, LDL-c } \\
\text { levels, LDL-c to HDL-c } \\
\text { ratio. } \\
\text { Antioxidant effect: } \\
\text { increase the stability and } \\
\text { association of PON/ with } \\
\text { HDL }\end{array}$} & $\begin{array}{l}\text { Diabetic patients were supplemented with } \\
\text { concentrated pomegranate juice for eight weeks. }\end{array}$ & $\begin{array}{l}\text { Esmaillzadeh } \\
\text { et al, } 2006^{84}\end{array}$ \\
\hline & & & & $\begin{array}{l}\text { Patients with type } 2 \text { diabetes were administered } \\
\text { pomegranate fruit juice or pomegranate } \\
\text { polyphenol extracts. }\end{array}$ & $\begin{array}{l}\text { Rock et al, } \\
2008^{85}\end{array}$ \\
\hline 10 & Strawberry & $\begin{array}{l}\text { Ellagic acid } \\
\text { Catechins } \\
\text { Kaempferol } \\
\text { Anthocyanins }\end{array}$ & $\begin{array}{l}\text { Hypolipidemic function: } \\
\text { - Reduces LDL-c levels, } \\
\text { LDL-c to HDL-c ratio. } \\
\text { - Reduces Ox-LDL levels } \\
\text { Antioxidant effect: } \\
\text { increase the stability and } \\
\text { association of PON/ with } \\
\text { HDL }\end{array}$ & $\begin{array}{l}\text { Hyperlipidemic adults were supplemented with a } \\
\text { strawberry beverage containing approximately } \\
338 \mathrm{mg} \text { total phenolic compounds over a six- } \\
\text { week period. }\end{array}$ & $\begin{array}{l}\text { Burton- } \\
\text { Freeman et } \\
\text { al, } 2010^{86}\end{array}$ \\
\hline
\end{tabular}

CSF signaling, and in turn a respiratory ailment could lead to dysbiosis. ${ }^{113}$

Several studies reported alleviation of symptoms of the common cold and a reduction in its duration by supplementation with Lactobacillus plantarum HEAL9 (DSM 15312) and Lactobacillus paracasei 8700:2 (DSM $13434)$ at a concentration of $1 \dot{\times} 10^{9} \mathrm{cfu} / \mathrm{day}^{115}$ and Lactobacillus gasseri PA 16/8, Bifidobacterium longum SP 07/3, Bifidobacterium bifidum MF $20 / 5$ at a concentration of $5 \times 10^{7} \mathrm{cfu} /$ day. ${ }^{116}$ When these probiotics were administered along with the influenza vaccine, an increase in the antibody titer was observed. ${ }^{117}$ An ongoing clinical trial is noteworthy in this regard. ${ }^{118,119}$

Prebiotics too have a beneficial role in conferring anti-inflammatory activity by inducing the production of IL-10 and IL-17. ${ }^{120}$ The short chain fatty acids (SCFA) like acetate and butyrate activate FFA receptors, leading to a downregulation of $\mathrm{NF \kappa B}$ and MAPK 
Table 6 Natural Products and Their Bioactive Molecules Exhibiting Anti-obesity, Antidiabetic and Hypolipidemic Effects

\begin{tabular}{|c|c|c|c|c|c|}
\hline $\begin{array}{l}\text { Natural } \\
\text { Products }\end{array}$ & $\begin{array}{l}\text { Bioactive } \\
\text { Molecules }\end{array}$ & Sources & Clinical Trials & Observed Results & $\begin{array}{l}\text { Study, Year, } \\
\text { Reference }\end{array}$ \\
\hline \multirow[t]{5}{*}{ PUFA } & \multirow{5}{*}{$\begin{array}{l}\text { Docosahexaenoic } \\
\text { acid (DHA) } \\
\text { Eicosapentaenoic } \\
\text { acid (EPA) } \\
\text { Conjugated } \\
\text { linolenic acid } \\
\text { (CLA) } \\
\text { Arachidonic acid } \\
\text { (ALA) }\end{array}$} & \multirow[t]{5}{*}{$\begin{array}{l}\text { Fish oil } \\
\text { Flaxseed }\end{array}$} & $\begin{array}{l}\text { Male mice were fed high-fat and } \\
\text { high-glucose diet with I\% EPA } \\
\text { supplementation for four weeks }\end{array}$ & $\begin{array}{l}\text { Hypolipidemic function: } \\
\text { Regulate fat oxidation by } \\
\text { enhancing } \beta \text {-oxidation } \\
\text { Improves insulin sensitivity }\end{array}$ & $\begin{array}{l}\text { Liu et al, } \\
2013^{87}\end{array}$ \\
\hline & & & $\begin{array}{l}\text { PPAR } \alpha \text { null mice were fed high fat } \\
\text { diet with } 8 \% \text { fish oil for two weeks }\end{array}$ & $\begin{array}{l}\text { Anti-hyperglycemic function: } \\
\text { hepatic insulin resistance, induced } \\
\text { through high fat diet is prevented } \\
\text { via PARR pathway }\end{array}$ & $\begin{array}{l}\text { Neschen et al, } \\
2007^{88}\end{array}$ \\
\hline & & & $\begin{array}{l}\text { Male mice were fed high-fat diet } \\
\text { with } 6 \% \text { EPA and } 51 \% \text { DHA }\end{array}$ & $\begin{array}{l}\text { Anti-obesity function: } \\
\text { upregulation of PPARGCIA }\end{array}$ & $\begin{array}{l}\text { Flachs et al, } \\
2005^{89}\end{array}$ \\
\hline & & & $\begin{array}{l}\text { A three-week study was carried } \\
\text { out where male mice were fed a } \\
\text { diet of } 4.5 \% \text { fat and } 0.26 \% \text { omega- } 3 \\
\text { fatty acids and from second week } \\
\text { it was subjected to a four-day } \\
\text { treatment of protectin followed by } \\
\text { induced infection. }\end{array}$ & $\begin{array}{l}\text { Restoring homeostasis: } \\
\text { Protectins from DHA resolve } \\
\text { inflammation in the lungs and } \\
\text { function as SPMs }\end{array}$ & $\begin{array}{l}\text { Levy et al, } \\
2010^{90}\end{array}$ \\
\hline & & & $\begin{array}{l}\text { In vitro studies were carried out in } \\
\text { alveolar cells obtained from } \\
\text { asthmatic patients }\end{array}$ & $\begin{array}{l}\text { Restoring homeostasis: } \\
\text { EPA and DHA inhibit inflammatory } \\
\text { responses in asthmatic alveolar } \\
\text { macrophages with EPA being more } \\
\text { potent than DHA }\end{array}$ & $\begin{array}{l}\text { Mickleborough } \\
\text { et al, } 2009^{91}\end{array}$ \\
\hline \multicolumn{6}{|l|}{ Flavonoids } \\
\hline \multirow[t]{2}{*}{ Anthocyanins } & \multirow[t]{2}{*}{$\begin{array}{l}\text { Cyanidin } \\
\text { Cyanidin-3- } \\
\text { glucoside }\end{array}$} & \multirow[t]{2}{*}{$\begin{array}{l}\text { Red berries } \\
\text { Legumes }\end{array}$} & $\begin{array}{l}\text { Male apoE }{ }^{-1-} \text { mice were fed a diet } \\
\text { with } 1.25 \%(\mathrm{w} / \mathrm{w}) \text { black elderberry } \\
\text { extract for six weeks }\end{array}$ & $\begin{array}{l}\text { Antioxidant effect: } \\
\text { Increases the activity of PONI }\end{array}$ & $\begin{array}{l}\text { Farrell et al, } \\
2015^{92}\end{array}$ \\
\hline & & & $\begin{array}{l}\text { A randomized, double-blind trial } \\
\text { was conducted on } 29 \text { diabetic } \\
\text { patients supplemented with } 160 \\
\mathrm{mg} \text { of anthocyanins (from bilberry } \\
\text { and blackcurrant) twice a day for } \\
24 \text { weeks. }\end{array}$ & $\begin{array}{l}\text { Preventing dyslipidemia: } \\
\text { anthocyanin supplementation } \\
\text { reduced the serum triglycerides level } \\
\text { Anti-hyperglycemic function: } \\
\text { supplementation increased } \\
\text { adiponectin levels in diabetic patients } \\
\text { leading to lower blood glucose } \\
\text { concentration }\end{array}$ & Li et al, $2015^{93}$ \\
\hline \multirow[t]{2}{*}{ Flavanols } & \multirow[t]{2}{*}{$\begin{array}{l}\text { Catechins } \\
\text { (epicatechins, } \\
\text { epigallocatechins, } \\
\text { etc) }\end{array}$} & \multirow[t]{2}{*}{ Green tea } & $\begin{array}{l}\text { Male mice were fed diet } \\
\text { supplemented with EGCG }(0.25- \\
I \% \mathrm{w} / \mathrm{w}) \text { for five weeks. }\end{array}$ & $\begin{array}{l}\text { Preventing dyslipidemia: } \\
\text { increases fatty acid oxidation } \\
\text { Anti-hyperglycemic function: } \\
\text { Increases stimulation of insulin } \\
\text { secretion }\end{array}$ & $\begin{array}{l}\text { Wolframet al, } \\
2006^{94}\end{array}$ \\
\hline & & & $\begin{array}{l}\text { Male C57BL/6 J mice were fed high } \\
\text { fat diet and a supplement of } \\
\text { epicatechin ( } 20 \mathrm{mg} \mathrm{EC/kg} \text { body } \\
\text { weight) }\end{array}$ & $\begin{array}{l}\text { Anti-hyperglycemic function: } \\
\text { improves insulin sensitivity }\end{array}$ & $\begin{array}{l}\text { Cremonini et } \\
\text { al, } 2016^{95}\end{array}$ \\
\hline
\end{tabular}

(Continued) 
Table 6 (Continued).

\begin{tabular}{|c|c|c|c|c|c|}
\hline $\begin{array}{l}\text { Natural } \\
\text { Products }\end{array}$ & $\begin{array}{l}\text { Bioactive } \\
\text { Molecules }\end{array}$ & Sources & Clinical Trials & Observed Results & $\begin{array}{l}\text { Study, Year, } \\
\text { Reference }\end{array}$ \\
\hline \multirow[t]{6}{*}{ Flavonols } & Quercetin & $\begin{array}{l}\text { Onion } \\
\text { Apples }\end{array}$ & $\begin{array}{l}\text { In vitro studies were performed to } \\
\text { observe the effect of quercetin } \\
\text { (onion peel extract) on } 3 \text { T3-LI } \\
\text { pre-adipocyte cells. } \\
\text { Male rats fed high fat diet were } \\
\text { treated with quercetin (onion peel } \\
\text { extract). }\end{array}$ & $\begin{array}{l}\text { Preventing dyslipidemia and } \\
\text { regulating obesity: } \\
\text { in vitro studies showed a } \\
\text { reduction in the triglycerides levels } \\
\text { as well as lipid accumulation. } \\
\text { In vivo studies showed that the } \\
\text { mRNA expressions of several } \\
\text { genes involved in lipid oxidation } \\
\text { were regulated and hence also } \\
\text { exhibit anti-obesity effects. }\end{array}$ & $\begin{array}{l}\text { Moonet al, } \\
2013^{96}\end{array}$ \\
\hline & & & $\begin{array}{l}\text { In vitro studies were performed to } \\
\text { observe the effect of quercetin } \\
\text { (onion peel extract) on 3T3-LI } \\
\text { pre-adipocyte cells. }\end{array}$ & $\begin{array}{l}\text { Preventing dyslipidemia and } \\
\text { regulating obesity: } \\
\text { onion peel extract upregulated the } \\
\mathrm{PGCl} \alpha \text { expression and quercetin of } \\
\mathrm{I00} \mu \mathrm{M} \text { increased protein levels of } \\
\mathrm{PGCl} \alpha \text {. }\end{array}$ & $\begin{array}{l}\text { Lee et al, } \\
2017^{97}\end{array}$ \\
\hline & & & $\begin{array}{l}\text { Male rats were fed a liquid diet } \\
\text { containing quercetin }(10 \mathrm{mg} / \mathrm{L}) \text { for } \\
\text { four weeks and compared to } \\
\text { control (diet without quercetin) }\end{array}$ & $\begin{array}{l}\text { Antioxidant effect: } \\
\text { quercetin-fed rats showed an } \\
\text { increase in hepatic PONI } \\
\text { expression and its activity. }\end{array}$ & $\begin{array}{l}\text { Gong et al, } \\
2009^{98}\end{array}$ \\
\hline & & & $\begin{array}{l}\text { Obese rats were fed diet } \\
\text { supplemented with quercetin ( } 2 \\
\mathrm{mg} / \mathrm{kg} \text { of body weight or } 10 \mathrm{mg} / \mathrm{kg} \\
\text { of body weight) }\end{array}$ & $\begin{array}{l}\text { Preventing dyslipidemia: } \\
\text { both doses reduced hyperlipidemia } \\
\text { Antidiabetic function: } \\
\text { Both doses reduced insulin } \\
\text { resistance. } \\
\text { Anti-inflammatory effects: } \\
\text { higher dosage of } 10 \mathrm{mg} / \mathrm{kg} \text { of body } \\
\text { weight caused a decrease in the } \\
\text { levels of pro-inflammatory } \\
\text { cytokines (TNF- } \alpha \text { in adipose tissues } \\
\text { and plasma NOx). } \\
\text { Anti-obesity function: } \\
\text { higher dosage also resulted in } \\
\text { weight loss }\end{array}$ & $\begin{array}{l}\text { Rivera et al, } \\
2008^{99}\end{array}$ \\
\hline & Kaempferol & Pomegranate & $\begin{array}{l}\text { Diabetic rats were treated with } \\
\text { kaempferol }(50 \text { or } 150 \mathrm{mg} / \mathrm{kg} \text { ) }\end{array}$ & $\begin{array}{l}\text { Increases insulin sensitivity by } \\
\text { inhibiting the NFKB pathway and } \\
\text { restoring IRS-I function. }\end{array}$ & $\begin{array}{l}\text { Luo et al, } \\
2015^{100}\end{array}$ \\
\hline & & & $\begin{array}{l}\text { In vitro studies were carried out on } \\
\text { INS-IE beta-cells and human islets } \\
\text { treated with } 10 \mu \mathrm{M} \text { of kaempferol. }\end{array}$ & $\begin{array}{l}\text { Antidiabetic function: } \\
\text { Increases translational activation of } \\
\text { insulin }\end{array}$ & $\begin{array}{l}\text { Zhang and Liu, } \\
2011^{101}\end{array}$ \\
\hline
\end{tabular}

(Continued) 
Table 6 (Continued).

\begin{tabular}{|c|c|c|c|c|c|}
\hline $\begin{array}{l}\text { Natural } \\
\text { Products }\end{array}$ & $\begin{array}{l}\text { Bioactive } \\
\text { Molecules }\end{array}$ & Sources & Clinical Trials & Observed Results & $\begin{array}{l}\text { Study, Year, } \\
\text { Reference }\end{array}$ \\
\hline & Tiliroside & $\begin{array}{l}\text { Strawberry } \\
\text { Raspberry }\end{array}$ & $\begin{array}{l}\text { Obese-diabetic mice were } \\
\text { administered tiliroside (100 mg/kg } \\
\text { body weight/day) for three weeks. }\end{array}$ & $\begin{array}{l}\text { Hypolipidemic function: } \\
\text { enhanced adiponectin signalling } \\
\text { leading to FA oxidation. } \\
\text { Reduced TG levels. } \\
\text { Restoring homeostasis: } \\
\text { activated PPAR } \alpha \text { pathway in the } \\
\text { liver and the AMPK pathway in the } \\
\text { liver as well as skeletal muscles. }\end{array}$ & $\begin{array}{l}\text { Gotoet al, } \\
2012^{102}\end{array}$ \\
\hline \multirow[t]{4}{*}{ Flavanones } & $\begin{array}{l}\text { Naringenin } \\
\text { (aglycone) } \\
\text { Naringin (glycone) }\end{array}$ & $\begin{array}{l}\text { Citrus fruits } \\
\text { (oranges, } \\
\text { lemon) } \\
\text { Grapefruit } \\
\text { Tomatoes } \\
\text { Cocoa }\end{array}$ & $\begin{array}{l}\text { Male diabetic rats were treated } \\
\text { with naringenin }(25 \mathrm{mg} / \mathrm{kg} \text { body } \\
\text { weight) for } 45 \text { days. }\end{array}$ & $\begin{array}{l}\text { Hypolipidemic function: } \\
\text { naringenin treatment resulted in } \\
\text { lowering of triglycerides, free fatty } \\
\text { acids, LDL levels and increase in } \\
\text { HDL levels. } \\
\text { Prevented lipid oxidation. } \\
\text { Antidiabetic function: } \\
\text { Naringenin treatment upregulated } \\
\text { GLUT-4 and downregulated TNF- } \alpha \\
\text { expressions. }\end{array}$ & $\begin{array}{l}\text { Priscillaet al, } \\
2015^{103}\end{array}$ \\
\hline & & & $\begin{array}{l}\text { Type } 2 \text { diabetic rats fed high fat } \\
\text { diet were supplemented with } \\
\text { naringin ( } 50 \mathrm{mg} / \mathrm{kg} \text { body weight) } \\
\text { for } 30 \text { days. }\end{array}$ & $\begin{array}{l}\text { Hypolipidemic function: } \\
\text { decrease in serum levels of free } \\
\text { fatty acids (FFA). } \\
\text { Increases HDL-c levels. } \\
\text { Increases serum adiponectin levels. } \\
\text { Anti-hyperglycemic function: } \\
\text { Improves insulin sensitivity }\end{array}$ & $\begin{array}{l}\text { Ahmed et al, } \\
2012^{104}\end{array}$ \\
\hline & Hesperidin & $\begin{array}{l}\text { Citrus fruits } \\
\text { (oranges, } \\
\text { lemon) } \\
\text { Grapefruit }\end{array}$ & $\begin{array}{l}\text { Mice were fed high fat diet } \\
\text { supplemented with hesperidin. }\end{array}$ & $\begin{array}{l}\text { Anti-obesity function: } \\
\text { reduced body fat accumulation } \\
\text { Hypolipidemic function: } \\
\text { Reduced LDL levels. }\end{array}$ & $\begin{array}{l}\text { Liu et al, } \\
2020^{105}\end{array}$ \\
\hline & & & $\begin{array}{l}\text { Type } 2 \text { diabetic rats fed high fat } \\
\text { diet were supplemented with } \\
\text { hesperidin }(50 \mathrm{mg} / \mathrm{kg} \text { body weight) } \\
\text { for } 30 \text { days. }\end{array}$ & $\begin{array}{l}\text { Hypolipidemic function: } \\
\text { increased HDL-c levels. }\end{array}$ & $\begin{array}{l}\text { Ahmed et al, } \\
2012^{104}\end{array}$ \\
\hline Flavones & $\begin{array}{l}\text { Luteolin } \\
\text { Apigenin } \\
\text { Chrysin } \\
\text { Tangeritin }\end{array}$ & $\begin{array}{l}\text { Celery } \\
\text { Thyme } \\
\text { Chamomile } \\
\text { tea } \\
\text { Honey } \\
\text { Oranges } \\
\text { Onions } \\
\text { Grapefruit }\end{array}$ & $\begin{array}{l}\text { Diabetes induced male rats with } \\
\text { induced diabetes received a } \\
\text { treatment of either chrysin }(0.25 \% \\
\mathrm{w} / \mathrm{w}) \text { or luteolin }(1 \% \mathrm{w} / \mathrm{w})\end{array}$ & $\begin{array}{l}\text { Hypolipidemic function: } \\
\text { luteolin and chrysin reduced the } \\
\text { levels of triglycerides and total } \\
\text { cholesterol. }\end{array}$ & $\begin{array}{l}\text { El-Bassossy et } \\
\text { al, } 2013^{106}\end{array}$ \\
\hline
\end{tabular}

(Continued) 
Table 6 (Continued).

\begin{tabular}{|c|c|c|c|c|c|}
\hline $\begin{array}{l}\text { Natural } \\
\text { Products }\end{array}$ & $\begin{array}{l}\text { Bioactive } \\
\text { Molecules }\end{array}$ & Sources & Clinical Trials & Observed Results & $\begin{array}{l}\text { Study, Year, } \\
\text { Reference }\end{array}$ \\
\hline & & & $\begin{array}{l}\text { Male rats with fructose-induced } \\
\text { hyperinsulinemia received a } \\
\text { treatment of either chrysin }(0.25 \% \\
w / w) \text { or luteolin }(1 \% \mathrm{w} / \mathrm{w})\end{array}$ & $\begin{array}{l}\text { Hypolipidemic function: } \\
\text { luteolin and chrysin reduced the } \\
\text { levels of LDL-c } \\
\text { Anti-hyperglycemic function: } \\
\text { reduced insulin resistance } \\
\text { Restoring homeostasis: } \\
\text { luteolin and chrysin stimulated } \\
\text { PPAR } \gamma \text { activity }\end{array}$ & $\begin{array}{l}\text { El-Bassossy et } \\
\text { al, } 2014^{107}\end{array}$ \\
\hline & & & $\begin{array}{l}\text { Male C57BL/ } 6 \text { mice were fed high } \\
\text { fat diet supplemented with } 0.01 \% \\
\text { luteolin for } 20 \text { weeks. }\end{array}$ & $\begin{array}{l}\text { Hypolipidemic function: } \\
\text { activated AMPK } \alpha \text { I in macrophages } \\
\text { present in the adipose tissues. }\end{array}$ & $\begin{array}{l}\text { Zhang et al, } \\
2016^{108}\end{array}$ \\
\hline \multirow[t]{2}{*}{ Isoflavones } & Genistein & Soy & $\begin{array}{l}\text { In vitro analysis of effects of } \\
\text { genistein }(5 \mu \mathrm{M}) \text { on INS-IE cells } \\
\text { for } 48 \mathrm{~h} \text { exposure was carried out. }\end{array}$ & $\begin{array}{l}\text { Antidiabetic function: } \\
\text { increased insulin secretion by the } \\
\text { pancreatic } \beta \text {-cells. }\end{array}$ & $\begin{array}{l}\text { Fu and Liu, } \\
2009^{109}\end{array}$ \\
\hline & Rutin & $\begin{array}{l}\text { Apricots } \\
\text { Cherries } \\
\text { Grapes } \\
\text { Plums }\end{array}$ & $\begin{array}{l}\text { Obese rats were fed rutin (100 } \\
\mathrm{mg} / \mathrm{kg}) \text { for eight weeks. }\end{array}$ & $\begin{array}{l}\text { Anti-obesity function: } \\
\text { decreased body fat accumulation }\end{array}$ & $\begin{array}{l}\text { Hsu et al, } \\
2009^{110}\end{array}$ \\
\hline \multirow[t]{4}{*}{$\begin{array}{l}\text { Phenolic } \\
\text { acids }\end{array}$} & Coumaric acid & $\begin{array}{l}\text { Peanuts } \\
\text { Tomatoes } \\
\text { Basil } \\
\text { Garlic } \\
\text { Spinach }\end{array}$ & $\begin{array}{l}\text { Obese rats were fed o-coumaric } \\
\text { acid }(100 \mathrm{mg} / \mathrm{kg}) \text { for eight weeks. }\end{array}$ & $\begin{array}{l}\text { Hypolipidemic function: } \\
\text { decreased LDL-c levels }\end{array}$ & $\begin{array}{l}\text { Hsu et al, } \\
2009^{110}\end{array}$ \\
\hline & & & $\begin{array}{l}\text { Type } 2 \text { diabetic rats were fed p- } \\
\text { coumaric acid of } 40 \mathrm{mg} / \mathrm{kg} \text { of body } \\
\text { mass for six weeks. }\end{array}$ & $\begin{array}{l}\text { Antihyperglycemic function: } \\
\text { Increased HDL-c levels in serum. } \\
\text { Decreased LDL-c, TG, TC levels. } \\
\text { Antihyperglycemic function: } \\
\text { Improves } \beta \text {-cell function. } \\
\text { Restoring homeostasis: } \\
\text { Increased the expression of PPAR } \gamma \text {. }\end{array}$ & $\begin{array}{l}\text { Abdel-Moneim } \\
\text { et al, } 2018^{111}\end{array}$ \\
\hline & Gallic acid & $\begin{array}{l}\text { Tea leaves } \\
\text { Dates } \\
\text { Cloves } \\
\text { Chicory }\end{array}$ & $\begin{array}{l}\text { Rats were fed high-fructose diet } \\
\text { and were supplemented with gallic } \\
\text { acid ( } 40 \mathrm{mg} / \mathrm{kg} \text { body weight) for } \\
\text { four weeks. }\end{array}$ & $\begin{array}{l}\text { Hypolipidemic function: } \\
\text { reduced TC, TG, LDL-c levels. } \\
\text { Increased HDL-c levels. } \\
\text { Increases levels of adiponectin. } \\
\text { Anti-hyperglycemic function: } \\
\text { reduces plasma insulin levels. }\end{array}$ & $\begin{array}{l}\text { Ibitoye and } \\
\text { Ajiboye, } \\
2018^{112}\end{array}$ \\
\hline & & & $\begin{array}{l}\text { Type } 2 \text { diabetic rats were fed gallic } \\
\text { acid of } 20 \mathrm{mg} / \mathrm{kg} \text { of body mass for } \\
\text { six weeks. }\end{array}$ & $\begin{array}{l}\text { Anti-hyperglycemic function: } \\
\text { increased HDL-c levels in serum. } \\
\text { Restored adiponectin levels } \\
\text { Anti-hyperglycemic function: } \\
\text { restored } \beta \text {-cell function. } \\
\text { Reduced insulin resistance. } \\
\text { Restoring homeostasis: } \\
\text { increased the expression of PPAR } \gamma \text {. }\end{array}$ & $\begin{array}{l}\text { Abdel-Moneim } \\
\text { et al, } 2018^{111}\end{array}$ \\
\hline
\end{tabular}

(Continued) 
Table 6 (Continued).

\begin{tabular}{|l|l|l|l|l|l|}
\hline $\begin{array}{l}\text { Natural } \\
\text { Products }\end{array}$ & $\begin{array}{l}\text { Bioactive } \\
\text { Molecules }\end{array}$ & Sources & Clinical Trials & Observed Results & $\begin{array}{l}\text { Study, Year, } \\
\text { Reference }\end{array}$ \\
\hline & Caffeic acid & $\begin{array}{l}\text { Coffee } \\
\text { Apples } \\
\text { Pears }\end{array}$ & $\begin{array}{l}\text { Rats were fed high-fructose diet } \\
\text { and were supplemented with } \\
\text { caffeic acid }(40 \mathrm{mg} / \mathrm{kg} \text { body weight) } \\
\text { for four weeks. }\end{array}$ & $\begin{array}{l}\text { Hypolipidemic function: } \\
\text { reduced TC, TG, LDL-c levels. } \\
\text { Increased HDL-c levels. } \\
\text { Increases levels of adiponectin. } \\
\text { Anti-hyperglycemic function: } \\
\text { reduces plasma insulin levels. }\end{array}$ & $\begin{array}{l}\text { Ajiboye, } \\
2018^{1 / 2}\end{array}$ \\
& Ferulic acid & $\begin{array}{l}\text { Oats } \\
\text { Pineapple } \\
\text { Rice } \\
\text { Wheat } \\
\text { Peanuts }\end{array}$ & $\begin{array}{l}\text { Rats were fed high-fructose diet } \\
\text { and were supplemented with gallic } \\
\text { acid (40 mg/kg body weight) for } \\
\text { four weeks. }\end{array}$ & $\begin{array}{l}\text { Hypolipidemic function: } \\
\text { reduced TC, TG, LDL-c levels. } \\
\text { Increased HDL-c levels. } \\
\text { Increases levels of adiponectin. } \\
\text { Anti-hyperglycemic function: } \\
\text { reduces plasma insulin levels. }\end{array}$ & $\begin{array}{l}\text { Ajiboye, } \\
2018^{1 / 2}\end{array}$ \\
& $\begin{array}{l}\text { Protocatechuic } \\
\text { acid }\end{array}$ & $\begin{array}{l}\text { Plums } \\
\text { Grapes } \\
\text { Almonds }\end{array}$ & $\begin{array}{l}\text { Rats were fed high-fructose diet } \\
\text { and were supplemented with gallic } \\
\text { acid (40 mg/kg body weight) for } \\
\text { four weeks. }\end{array}$ & $\begin{array}{l}\text { Hypolipidemic function: } \\
\text { reduced TC, TG, LDL-c levels. } \\
\text { Increased HDL-c levels. } \\
\text { Increases levels of adiponectin. } \\
\text { Anti-hyperglycemic function: } \\
\text { reduces plasma insulin levels. }\end{array}$ \\
\hline
\end{tabular}

pathways. $^{121}$ The levels of certain LPS-induced proinflammatory cytokines and chemokines, like TNF- $\alpha$, CXCL8, CCL20 show downregulation during butyrate administration to the system. ${ }^{120}$ SCFAs also exhibit immunomodulatory functions by regulating the function of $\mathrm{T}$ cells. ${ }^{120}$ Oat bran and psyllium husk fiber act as natural prebiotic by undergoing fermentation by the gut microbiota to yield SCFA. These can also bind to PPARs and facilitate homeostasis. ${ }^{122}$

\section{Bioactive Peptides and Other Natural Molecules and Their Immunomodulatory Actions}

Some of the bioactive peptides that have shown beneficial effects in reducing inflammation and functioning as antioxidants are summarized in Table 7.

\section{Vitamin C}

Vitamin C (ascorbic acid) possesses antioxidant and immune-modulatory property. It helps in mitigating the injury caused by oxidative stress during viral infections. ${ }^{135}$ Patients suffering from ARDS show reduced levels of vitamin $\mathrm{C}$ (Vit $\mathrm{C}$ ) and external administration of Vit $\mathrm{C}$ reduced the extent of pulmonary inflammation in ARDS. $^{136}$ With inflammation being a major cause of severity of COVID-19, supplementation with Vit C is hypothesized to aid in counteracting the actions of proinflammatory cytokines, especially IL-6. Treatment with Vit C (500 mg twice a day) ${ }^{137}$ and its intravenous administration (doses of 6 to $12 \mathrm{~g}$ /day and $24 \mathrm{~g}$ /day for seven days) (NCT04264533) reduces the levels of IL-6 and other inflammatory cytokines (ferritin and D-dimer). ${ }^{138}$ Vit $\mathrm{C}$ as an adjunct treatment could help in reducing the pneumonia-like symptoms and significantly reduce the mortality rates. $^{139}$

Clinical trials are being carried out with a combinatorial treatment of Vit $\mathrm{C}$ along with other substances such as quercetin, vitamin $\mathrm{D}$ and zinc in different formats (IV or oral dosages) to treat COVID-19. ${ }^{137}$ Co-administering quercetin with Vit $\mathrm{C}$ and vitamin Vit B3 in mice with stress-induced H1N1 infection showed a delay in the time-to-death and reduced the mortality, as opposed to administration of single vitamins. ${ }^{140}$ A similar co-administration of Vit $\mathrm{C}$ along with quercetin, vitamins $\mathrm{D}$ and $\mathrm{B} 3$ could help to ameliorate the symptoms of severe COVID19 cases. Vit $\mathrm{C}$ is known to increase the efficacy of quercetin $^{139}$ and a combinatorial therapy of quercetin (500 mg) - Vit C (500 mg)_bromelain (50 mg) as a prophylactic treatment on health-care workers was found to be effective over a three-month study. ${ }^{141}$ 
Table 7 Bioactive Peptides and Their Functional Properties in Ameliorating Metabolic Diseases

\begin{tabular}{|c|c|c|}
\hline Bioactive Peptides & Activity & Study, Year, Reference \\
\hline $\begin{array}{l}\text { Casein hydrolysates (eg VPP, IPP, } \\
\text { QEPV, glycomacropeptide (GMP) } \\
\text { etc) }\end{array}$ & $\begin{array}{l}\text { Inhibit c-Jun N-terminal kinase (JNK) pathway, exhibit hypolipidemic effects, } \\
\text { increase levels of IL-10 }\end{array}$ & $\begin{array}{l}\text { Chakrabarti and Wu, 20I5; } \\
\text { Ortega-González et al, 20I4; } \\
\text { Nakamura et al, 2013, }\end{array}$ \\
\hline Whey protein hydrolysates & Reduce IL-8 levels in pathogen infected respiratory cells & Iskandar et al, 2013, ${ }^{126}$ \\
\hline Egg tripeptides (eg IRW, IQW) & Inhibit NFKB pathway, regulate RAAS pathway & Majumder et al, $2013,^{127}$ \\
\hline $\begin{array}{l}\text { Soybean hydrolysates (eglunasin, } \\
\text { VPY, FLV) }\end{array}$ & $\begin{array}{l}\text { Inhibit NFKB pathway, reduce COX-2 levels, reduce cytokine storm (TNF- } \alpha \text {, } \\
\text { IL-6 and MCP-I) in airway inflammation, reduction of oxidative stress }\end{array}$ & $\begin{array}{l}\text { de Mejia and Dia, } 2009 ; \\
\text { Kovacs-Nolan et al } \\
2012^{128,129}\end{array}$ \\
\hline Fish protein hydrolysates (eg PAY) & Reduce obesity-induced inflammation, reduce levels of TNF- $\alpha$, IL- 6 and IL-I $\beta$ & Bjørndal et al, $2013^{130}$ \\
\hline Chicken collagen hydrolysate & Reduces levels of pro-inflammatory cytokines, regulate lipid profiles & Zhang et al, $2010^{131}$ \\
\hline Wheat gluten hydrolysate (eg pEL) & Reduce levels of TNF- $\alpha$ and IL-6, inhibit NFKB and MAPK pathway & $\begin{array}{l}\text { Suzuki et al, } 2011 \\
\text { Hirai et al, } 2014,^{132,133}\end{array}$ \\
\hline $\begin{array}{l}\text { Rye secalin-derived hydrolysates } \\
\text { (QCA, CQV, QVC, QCV) }\end{array}$ & Inhibit ADAM metallopeptidase domain I7 (ADAMI7) & Udechukwu et al, 2017,,$^{134}$ \\
\hline
\end{tabular}

\section{Vitamin D}

Studies have indicated the role of vitamin D (Vit D) in immune modulation. The review by Grant et al, ${ }^{142}$ mentions the different mechanisms by which Vit D may exert its antiviral effectiveness. It has been observed that Vit D downregulates the ACE2 receptors by negatively regulating the renin-angiotensin system (RAS). ${ }^{143} \mathrm{~A}$ recent study observed an association between COVID-19 severity and the high latitude countries which receive less sunlight leading to Vit D deficiency in people. However, this observation needs to be taken with the understanding that every population would show a mix of people suffering/ not suffering from Vit D deficiency and hence generalizations as such may be difficult. ${ }^{144}$

Ghavideldarestani et al ${ }^{145}$ suggested the role of Vit D in preventing local lung inflammation in COVID-19 patients. Angiotensin II through binding to the receptor AT1 can increase vasoconstriction, oxidative stress and inflammation. This angiotensin II can be cleaved by ACE2 into angiotensin1-7 which counteracts the harmful effects of angiotensin II. However, in patients with COVID-19, the ACE2 is hijacked by the virus for its entry and hence less of it is available for this regular physiological role. Vit D deficiency is shown to increase renin production thereby increasing $\mathrm{ACE}$ and angiotensin II production. This can lead to inflammation in the lungs that is observed in severe cases of COVID-19.

Glinsky ${ }^{16}$ took a gene-first approach to investigate potential therapeutic targets for COVID-19. They first identified the human genes responsible for the expression and function of ACE2 and FURIN, the attachment molecules of the virus. Next, they studied the expression profile of these genes when infected by the coronavirus. This was followed by searching the literature for molecules that may downregulate the concerned gene expression which led to the discovery of three potential therapeutic molecules-Vit $\mathrm{D}$, quercetin, and estradiol. Vit D was found to alter the expression of 84 of 332 (25\%) genes encoding human proteins that serve as target for the SARS-CoV-2. The author suggested a two-ingredient (quercetin-Vit D) or a three-ingredient (quercetin-Vit D-estradiol) formulation as an adjunct therapy for coronavirus patients. In fact, two clinical studies involving Vit D are already registered.

Given the potent antiviral effects of quercetin, especially in the crucial stages of viral entry and its replication, and the ability of ascorbic acid and Vit D to efficiently reduce the oxidative stress induced by inflammation and activate the RAS pathway, respectively, adjunct therapy with these molecules is an approach that warrants further research for its potential benefits.

\section{Lactoferrin}

Lactoferrin, experimentally, has been found to inhibit viral entry in murine coronavirus, and human coronaviruses hCOV-NL63 and pseudotype SARS-CoV. Besides preventing viral entry, lactoferrin can also suppress virus replication after the viral entry. Lactoferrin was shown to 
chelate ferritin thereby downregulating IL-6 and TNFalpha. There is a clinical trial currently underway to study the effect of lactoferrin as an adjunct therapy for COVID-19. ${ }^{146}$

\section{Conclusion}

Studies have hitherto revealed many details about the SARS-COV-2 virus infection. Although we have gained insights into the SARS-CoV-2 viral pathogenesis, a definitive treatment course is still distant. In such times, the intelligent way is to maintain the best possible health by taking suitable adjuvants to avoid falling ill.

It is evident that there are many ingredients that can be included in daily diet to possibly gain immunity or protection against coronavirus. Polyphenols, leguminous seeds containing plant protease inhibitors, as well as proteins, such as whey protein or jackfruit seed protein, could be incorporated in the daily diet. Other bioactive polyphenols, such as EGCG, GCG are common constituents of green tea, quercetin is found abundantly in apples while hesperetin is present in citric foods. These foods can also become components of daily diet. Spices such as turmeric, thyme, rosemary, garlic have anti-inflammatory properties and can be used in daily cuisine. In conclusion, the current review highlights the potential benefits of a range of nutraceuticals in the management of COVID-19. Further work aimed at clarifying the mechanisms of actions and potential therapeutic utility requires further investigation.

\section{Abbreviations}

WHO, World Health Organization; SARS-CoV, severe acute respiratory syndrome coronavirus; MERS-CoV, Middle East respiratory syndrome coronavirus; ACE2, angiotensin converting enzyme 2; TMPRSS2, transmembrane serine protease 2; 3CLPro, chymotrypsin like cysteine protease; MPro, main protease; nsps, nonstructural proteins; DMVs, double membrane vesicles; RdRp, RNA dependent RNA polymerase; PLPro, papain-like protease; FDA, Food and Drug Administration; GRAS, generally regarded as safe; EGCG, epigallocatechin gallate; GCG, gallocatechin gallate; URTIs, upper respiratory tract infections; UPR, unfolded protein response; ARDS, acute respiratory distress syndrome; PAMPs, pathogen-associated molecular pattern; PRRs, pattern recognition receptors; TLRs, toll-like receptors; IFNs, interferons; APCs, antigen presenting cells; MAPKs, mitogen-activated protein kinases; JNK, c-Janus kinase; LDL, low-density lipoprotein; HDL, high-density lipoprotein; SPMs, specialized proresolving mediators; SCFA, short chain fatty acids; RAS, renin-angiotensin system; ADAM17, ADAM metallopeptidase domain 17; ER, endoplasmic reticulum; RBD, receptor binding domain; CTD, C-terminal domain; NTD, N-terminal domain.

\section{Acknowledgments}

The authors are thankful to AIPL Director Mr Cyrus $\mathrm{P}$ Mistry for his unstinting support and motivation.

\section{Disclosure}

The authors are employees of Arna Immuno Ingredients Private Limited and report no other potential conflicts of interest in this work. This article/research received no external funding.

\section{References}

1. Astuti I, Ysrafil Y. Severe Acute Respiratory Syndrome Coronavirus 2 (SARS-CoV-2): an overview of viral structure and host response. Diabetes Metab Syndr Clin Res Rev. 2020;14 (4):407-412. doi:10.1016/j.dsx.2020.04.020

2. Rabaan AA, Al-Ahmed SH, Haque S, et al. SARS-CoV-2, SARS-CoV, and MERS-CoV: a comparative overview. Le Infez Med. 2020;2:174-184. doi:10.3366/edinburgh/97807486 32909.003.0011

3. Zhang X, Tan Y, Ling Y, et al. Viral and host factors related to the clinical outcome of COVID-19. Nature. 2020;583(7816):437440. doi:10.1038/s41586-020-2355-0

4. Huang Y, Yang C, Xu X. Structural and functional properties of SARS-CoV-2 spike protein: potential antivirus drug development for COVID-19. Acta Pharmacol Sin. 2020;41(9):1141-1149. doi:10.1038/s41401-020-0485-4

5. Xiao L, Sakagami H, Miwa N. ACE2: the key molecule for understanding the pathophysiology of severe and critical conditions of COVID-19: demon or angel? Viruses. 2020;12(5):20022003. doi:10.3390/v12050491

6. Bestle D, Heindl MR, Limburg H, et al. TMPRSS2 and furin are both essential for proteolytic activation and spread of SARS-CoV2 in human airway epithelial cells and provide promising drug targets. bioRxiv. 2020. doi:10.1101/2020.04.15.042085

7. Hoffmann M, Kleine-Weber H, Schroeder S, et al. SARS-CoV-2 cell entry depends on ACE2 and TMPRSS2 and is blocked by a clinically proven protease inhibitor. Cell. 2020;181(2):271-280. e8. doi:10.1016/j.cell.2020.02.052

8. Chen Y, Liu Q, Guo D. Emerging coronaviruses: genome structure, replication, and pathogenesis. J Med Virol. 2020;92(4):418423. doi: $10.1002 / \mathrm{jmv} .25681$

9. Farshi P, Kaya EC, Hashempour-Baltork F, Khosravi-Darani K. A comprehensive review on the effect of plant metabolites on coronaviruses: focusing on their molecular docking score and IC50 values. Preprints. 2020. doi:10.20944/preprints202005.0295.v1

10. Suravajhala R, Parashar A, Malik B, et al. Comparative docking studies on curcumin with COVID-19 proteins. Preprints. 2020;19:1-37. doi:10.20944/preprints202005.0439.v3

11. Yi L, Li Z, Yuan K, et al. Small molecules blocking the entry of Severe Acute Respiratory Syndrome Coronavirus into host cells. J Virol. 2004;78(20):11334-11339. doi:10.1128/jvi.78.20.1133411339.2004 
12. Lin SC, Ho CT, Chuo WH, Li S, Wang TT, Lin CC. Effective inhibition of MERS-CoV infection by resveratrol. BMC Infect Dis. 2017;17(1):1-10. doi:10.1186/s12879-017-2253-8

13. Joshi RS, Jagdale SS, Bansode SB, et al. Discovery of potential multi-target-directed ligands by targeting host-specific SARSCoV-2 structurally conserved main protease. J Biomol Struct Dyn. 2020;(May). doi:10.1080/07391102.2020.1760137

14. Nguyen TTH, Woo HJ, Kang HK, et al. Flavonoid-mediated inhibition of SARS coronavirus 3C-like protease expressed in Pichia pastoris. Biotechnol Lett. 2012;34(5):831-838. doi:10.10 07/s10529-011-0845-8

15. Lin CW, Tsai FJ, Tsai CH, et al. Anti-SARS coronavirus 3C-like protease effects of Isatis indigotica root and plant-derived phenolic compounds. Antiviral Res. 2005;68(1):36-42. doi:10.1016/j. antiviral.2005.07.002

16. Glinsky GV. Tripartite combination of potential pandemic mitigation agents: vitamin D, Quercetin, and Estradiol manifest properties of candidate medicinal agents for mitigation of the severity of pandemic COVID-19 defined by genomics-guided tracing of SARS-CoV-2 targ. Biomedicines. 2020;8(5):129.

17. Abian O, Ortega-Alarcon D, Jimenez-Alesanco A, et al Structural stability of SARS-CoV-2 3CLpro and identification of quercetin as an inhibitor by experimental screening. Int $J$ Biol Macromol. 2020;164. doi:10.1016/j.ijbiomac.2020.07.235

18. Nabirotchkin S, Peluffo AE, Bouaziz J, Cohen D. Focusing on the unfolded protein response and autophagy related pathways to reposition common approved drugs against COVID-19. Preprints. 2020.

19. Khan MF, Khan MA, Khan ZA, Ahamad T, Ansari WA Identification of dietary molecules as therapeutic agents to combat COVID-19 using molecular docking studies. Research Square. 2020. doi:10.21203/rs.3.rs-19560/v1

20. Umesh U, Kundu D, Selvaraj C, Singh SK, Dubey VK. Identification of new anti-nCoV drug chemical compounds from indian spices exploiting SARS-CoV-2 main protease as target. J Biomol Struct Dyn. 2020. doi:10.1080/07391102.20 20.1763202

21. Bosch-Barrera J, Martin-Castillo B, Buxó M, Brunet J, Encinar JA, Menendez JA. Silibinin and SARS-CoV-2: dual targeting of host cytokine storm and virus replication machinery for clinical management of COVID-19 patients. J Clin Med. 2020;9(6):1770. doi: $10.3390 / \mathrm{jcm} 9061770$

22. $\mathrm{Hu} \mathrm{X}$, Cai X, Song X, et al. Possible SARS-coronavirus 2 inhibitor revealed by simulated molecular docking to viral main protease and host toll-like receptor. Future Virol. 2020;15(6):359368. doi:10.2217/fvl-2020-0099

23. Kar P, Kumar V, Vellingiri B, et al. Anisotine and amarogentin as promising inhibitory candidates against SARS-CoV-2 proteins: a computational investigation. J Biomol Struct Dyn. 2020. doi:10.1080/07391102.2020.01860133

24. Kar P, Sharma NR, Singh B, Sen A, Roy A. Natural compounds from Clerodendrum spp. as possible therapeutic candidates against SARS-CoV-2: an in silico investigation. J Biomol Struct Dyn. 2020;1-12. doi:10.1080/07391102.2020.1780947

25. Fischer A, Sellner M, Neranjan S, Smieško M, Lill MA. Potential inhibitors for novel coronavirus protease identified by virtual screening of 606 million compounds. Int J Mol Sci. 2020;21 (10):1-17. doi:10.3390/ijms21103626

26. Das G, Das T, Chowdhury N, Chatterjee D, Bagchi A, Ghosh Z. Repurposed drugs and nutraceuticals targeting envelope protein: A possible therapeutic strategy against COVID-19. Genomics. 2020. doi:10.1016/j.ygeno.2020.11.009

27. Meyer M, Jaspers I. Respiratory protease/antiprotease balance determines susceptibility to viral infection and can be modified by nutritional antioxidants. fischer. 2015;308(12):1189-1201. doi:10.1152/ajplung.00028.2015
28. Vonder Haar C, Peterson TC, Martens KM, Hoane MR. Vitamins and nutrients as primary treatments in experimental brain injury: clinical implications for nutraceutical therapies. Brain Res. 2016;1640:114-129. doi:10.1016/j.brainres.2015.12.030

29. Olthof MR, Hollman PC, Zock PL, Katan MB. Consumption of high doses of chlorogenic acid, present in coffee, or of black tea increases plasma total homocysteine concentrations in humans. Am J Clin Nutr. 2001;73:3. doi:10.1093/ajen/73.3.532

30. Fear G, Komarnytsky S, Raskin I. Protease inhibitors and their peptidomimetic derivatives as potential drugs. Pharmacol Ther. 2007;113(2):354-368. doi:10.1016/j.pharmthera.2006.09.001

31. Sabotič J, Kos J. Microbial and fungal protease inhibitors-current and potential applications. Appl Microbiol Biotechnol. 2012;93:1351-1375. doi:10.1007/s00253-011-3834-x

32. van de Ven WJM, Voorberg J, Fontijn R, et al. Furin is a subtilisin-like proprotein processing enzyme in higher eukaryotes. Mol Biol Rep. 1990;14(4):265-275. doi:10.1007/BF00429896

33. Deng X, StJohn SE, Osswald HL, et al. Coronaviruses resistant to a 3C-Like protease inhibitor are attenuated for replication and pathogenesis, revealing a low genetic barrier but high fitness cost of resistance. J Virol. 2014;88(20):11886-11898. doi:10.1128/ jvi.01528-14

34. Hellinger R, Gruber CW. Peptide-based protease inhibitors from plants. Drug Discov Today. 2019;24(9):1877-1889. doi:10.1016/j. drudis.2019.05.026

35. Srikanth S, Chen Z. Plant protease inhibitors in therapeutics-focus on cancer therapy. Front Pharmacol. 2016;7:470. doi:10.3389/ fphar.2016.00470

36. Lega S, Naviglio S, Volpi S, Tommasini A. Recent insight into SARS-COV2 immunopathology and rationale for potential treatment and preventive strategies in COVID-19. Vaccines. 2020;8 (2):1-30. doi:10.3390/vaccines 8020224

37. Azkur AK, Akdis M, Azkur D, et al. Immune response to SARS$\mathrm{CoV}-2$ and mechanisms of immunopathological changes in COVID-19. Allergy Eur J Allergy Clin Immunol. 2020;75 (7):1564-1581. doi: 10.1111/all.14364

38. Oh HLJ, Gan SKE, Bertoletti A, Tan YJ. Understanding the T cell immune response in SARS coronavirus infection. Emerg Microbes Infect. 2012;1:23. doi:10.1038/emi.2012.26

39. Pedersen SF, Ho YC. SARS-CoV-2: A storm is raging. $J$ Clin Invest. 2020;130(5):2202-2205. doi:10.1172/JCI137647

40. Yuen KS, Ye ZW, Fung SY, Chan CP, Jin DY. SARS-CoV-2 and COVID-19: the most important research questions. Cell Biosci. 2020;10(1):1-5. doi:10.1186/s13578-020-00404-4

41. Mizutani T. Signal transduction in SARS-CoV-infected cells. Ann N Y Acad Sci. 2007;1102:86-95. doi:10.1196/annals.1408. 006

42. Pineau N, Aucouturier P, Brugier JC, Preud'homme JL. Jacalin: A lectin mitogenic for human CD4 T lymphocytes. Clin Exp Immunol. 1990;80(3):420-425. doi:10.1111/j.1365-2249.1990.tb0 3304.x

43. Al Mijan M, Lim BO. Diets, functional foods, and nutraceuticals as alternative therapies for inflammatory bowel disease: present status and future trends. World J Gastroenterol. 2018;24 (25):2673-2685. doi:10.3748/wjg.v24.i25.2673

44. Yang DJ, Liu SC, Chen YC, Hsu SH, Chang YP, Lin JT. Three pathways assess anti-inflammatory response of epicatechin with lipopolysaccharide-mediated macrophage RAW264.7 Cells. $J$ Food Biochem. 2015;39(3):334-343. doi:10.1111/jfbc.12134

45. Khan F, Niaz K, Maqbool F, et al. Molecular targets underlying the anticancer effects of quercetin: an update. Nutrients. 2016;8 (9):1-19. doi:10.3390/nu8090529

46. Choi JS, Choi YJ, Shin SY, et al. Dietary flavonoids differentially reduce oxidized LDL-induced apoptosis in human endothelial cells: role of MAPK- and JAK/STAT-signaling. $J$ Nutr. 2008;138(6):983-990. doi:10.1093/jn/138.6.983 
47. Hämäläinen $M$, Nieminen R, Vuorela $\mathrm{P}$, Heinonen $\mathrm{M}$, Moilanen E. Anti-inflammatory effects of flavonoids: genistein, kaempferol, quercetin, and daidzein inhibit STAT-1 and NF- $\mathrm{\kappa B}$ activations, whereas flavone, isorhamnetin, naringenin, and pelargonidin inhibit only NF- $\mathrm{KB}$ activation along with their inhibitory effect on iNOS expression and NO production in activated macrophages. Mediators Inflamm. 2007;2007:1-10.

48. Hsu SC, Chung JG. Anticancer potential of emodin. Biomed. 2012;2(3):108-116. doi:10.1016/j.biomed.2012.03.003

49. Kashyap D, Tuli HS, Sharma AK. Ursolic acid (UA): A metabolite with promising therapeutic potential. Life Sci. 2016;146:201213. doi:10.1016/j.1fs.2016.01.017

50. Huang MT, Ghai G, Ho CT. Inflammatory Process and Molecular Targets for Anti- inflammatory Nutraceuticals. Compr Rev Food Sci Food Saf. 2004;3(1):127-139.

51. Yanaka N, Koyama TA, Komatsu SI, Nakamura E, Kanda M, Kato N. Vitamin B6 suppresses NF-kappaB activation in LPSstimulated mouse macrophages. Int J Mol Med. 2005;16(6):10711075. doi:10.3892/ijmm.16.6.1071

52. Zhang L, Fan Y, Su H, et al. Chlorogenic acid methyl ester exerts strong anti-inflammatory effects: via inhibiting the COX-2/ NLRP3/NF-kB pathway. Food Funct. 2018;9(12):6155-6164. doi:10.1039/c8fo01281d

53. Dos Tramontin N, Luciano TF, de OMarques S, de Souza CT, Muller AP. Ginger and avocado as nutraceuticals for obesity and its comorbidities. Phytother Res. 2020;34(6):1282-1290. doi:10. $1002 /$ ptr.6619

54. Majdalawieh AF, Mansour ZR. Sesamol, a major lignan in sesame seeds (Sesamum indicum): anti-cancer properties and mechanisms of action. Eur $J$ Pharmacol. 2019;855:75-89. doi:10.1016/j.ejphar.2019.05.008

55. Sánchez-sánchez MA, Zepeda-morales ASM, Carrera-quintanar L, et al. Alliin, an Allium sativum nutraceutical, reduces metaflammation markers in DIO mice. Nutrients. 2020;12(3). doi:10. 3390/nu12030624

56. Nicholas C, Batra S, Vargo MA, et al. Apigenin blocks lipopolysaccharide-induced lethality in vivo and proinflammatory cytokines expression by inactivating NF- $\mathrm{KB}$ through the suppression of p65 phosphorylation. J Immunol. 2007;179(10):7121-7127. doi:10.4049/jimmunol.179.10.7121

57. Haghighatdoost F, Jabbari M, Hariri M. The effect of L-carnitine on inflammatory mediators: a systematic review and meta-analysis of randomized clinical trials. Eur J Clin Pharmacol. 2019. doi:10.1024/0300-9831/a000619

58. Marín-Aguilar F, Pavillard LE, Giampieri F, Bullón P, Cordero MD. Adenosine monophosphate (AMP)-activated protein kinase: A new target for nutraceutical compounds. Int $J$ Mol Sci. 2017;18:2. doi:10.3390/ijms18020288

59. Sunil C, Xu B. An insight into the health-promoting effects of taxifolin (dihydroquercetin). Phytochemistry. 2019;166 (July):112066. doi:10.1016/j.phytochem.2019.112066

60. Zaki N, Alashwal H, Ibrahim S. Association of hypertension, diabetes, stroke, cancer, kidney disease, and high-cholesterol with COVID-19 disease severity and fatality: A systematic review. Diabetes Metab Syndr Clin Res Rev. 2020;14(5):11331142. doi:10.1016/j.dsx.2020.07.005

61. Kim MS, Lee MS, Kown DY. Inflammation-mediated obesity and insulin resistance as targets for nutraceuticals. Ann N Y Acad Sci. 2011;1229(1):140-146. doi:10.1111/j.1749-6632.2011.06098.x

62. Kahn BB, Flier JS, Kahn BB, Flier JS. Obesity and insulin resistance find the latest version: obesity and insulin resistance. J Clin Invest. 2000;106(4):473-481.

63. Aggarwal BB. Targeting inflammation-induced obesity and metabolic diseases by curcumin and other nutraceuticals. Annu Rev Nutr. 2010;30:173-199. doi:10.1146/annurev.nutr. 012809.104755
64. Ayres JS. A metabolic handbook for the COVID-19 pandemic. Nat Metab. 2020;2(7):572-585. doi:10.1038/s42255-020-0237-2

65. Singh AK, Gupta R, Ghosh A, Misra A. Diabetes in COVID-19: prevalence, pathophysiology, prognosis and practical considerations. Diabetes Metab Syndr Clin Res Rev. 2020;14(4):303-310. doi:10.1016/j.dsx.2020.04.004

66. Rebello CJ, Kirwan JP, Greenway FL. Obesity, the most common comorbidity in SARS-CoV-2: is leptin the link? Int $J$ Obes. 2020;44(9):1810-1817. doi:10.1038/s41366-020-0640-5

67. Chen G, Wang H, Zhang X, Yang ST. Nutraceuticals and functional foods in the management of hyperlipidemia. Crit Rev Food Sci Nutr. 2014;54(9):1180-1201. doi:10.1080/10408398.2011. 629354

68. Sorokin AV, Karathanasis SK, Yang ZH, Freeman L, Kotani K, Remaley AT. COVID-19-Associated dyslipidemia: implications for mechanism of impaired resolution and novel therapeutic approaches. FASEB J. 2020;34(8):9843-9853. doi:10.1096/ fj.202001451

69. Houston M. The role of nutrition and nutraceutical supplements in the treatment of hypertension. World J Cardiol. 2014;6(2):38. doi:10.4330/wjc.v6.i2.38

70. Chao CY, Yin MC, Huang CJ. Wild bitter gourd extract upregulates mRNA expression of PPAR $\alpha$, PPAR $\gamma$ and their target genes in C57BL/6J mice. J Ethnopharmacol. 2011;135(1):156161. doi:10.1016/j.jep.2011.03.001

71. Sridhar MG, Vinayagamoorthi R, Arul Suyambunathan V, Bobby Z, Selvaraj N. Bitter gourd (Momordica charantia) improves insulin sensitivity by increasing skeletal muscle insulin-stimulated IRS-1 tyrosine phosphorylation in high-fat-fed rats. $\mathrm{Br} J$ Nutr. 2008;99(4):806-812. doi:10.1017/S000711450783176X

72. Misawa K, Hashizume K, Yamamoto M, Minegishi Y, Hase T, Shimotoyodome A. Ginger extract prevents high-fat diet-induced obesity in mice via activation of the peroxisome proliferatoractivated receptor $\delta$ pathway. $J$ Nutr Biochem. 2015;26 (10): 1058-1067. doi:10.1016/j.jnutbio.2015.04.014

73. Maharlouei N, Tabrizi R, Lankarani KB, et al. The effects of ginger intake on weight loss and metabolic profiles among overweight and obese subjects: A systematic review and meta-analysis of randomized controlled trials. Crit Rev Food Sci Nutr. 2019;59(11):1753-1766. doi:10.1080/10408398.2018.1427044

74. Shao W, Yu Z, Chiang Y, et al. Curcumin prevents high fat diet induced insulin resistance and obesity via attenuating lipogenesis in liver and inflammatory pathway in adipocytes. PLoS One. 2012;7(1):1-13. doi:10.1371/journal.pone.0028784

75. Panahi Y, Khalili N, Sahebi E, et al. Curcuminoids modify lipid profile in type 2 diabetes mellitus: A randomized controlled trial. Complement Ther Med. 2017;33:1-5. doi:10.1016/j.ctim.2017. 05.006

76. Lone J, Choi JH, Kim SW, Yun JW. Curcumin induces brown fatlike phenotype in 3T3-L1 and primary white adipocytes. $J$ Nutr Biochem. 2016;27:193-202. doi:10.1016/j.jnutbio.2015.09.006

77. Yousaf S, Butt MS, Suleria HAR, Iqbal MJ. The role of green tea extract and powder in mitigating metabolic syndromes with special reference to hyperglycemia and hypercholesterolemia. Food Funct. 2014;5(3):545-556. doi:10.1039/c3fo60203f

78. Hsu SP, Wu MS, Yang CC, et al. Chronic green tea extract supplementation reduces hemodialysisenhanced production of hydrogen peroxide and hypochlorous acid, atherosclerotic factors, and proinflammatory cytokines. Am J Clin Nutr. 2007;86 (5):1539-1547. doi:10.1093/ajen/86.5.1539

79. Kang JH, Kim CS, Han IS, Kawada T, Yu R. Capsaicin, a spicy component of hot peppers, modulates adipokine gene expression and protein release from obese-mouse adipose tissues and isolated adipocytes, and suppresses the inflammatory responses of adipose tissue macrophages. FEBS Lett. 2007;581(23):4389-4396. doi:10.1016/j.febslet.2007.07.082 
80. Jain PG, Patil SD, Haswani NG, Girase MV, Surana SJ. Atividade hipolipidemica de Moringa oleifera Lam., Moringaceae, na hiperlipidemia induzida por dieta rica em gordura em ratos albinos (Hypolipidemic activity of Moringa oleifera Lam., Moringaceae, on high fat diet induced hyperlipidemia in albino rats). Brazilian $J$ Pharmacogn. 2010;20(6):969-973. doi:10.1590/S0102-695X201 0005000038

81. Kumari DJ. Hypoglycaemic effect of Moringa oleifera and Azadirachta indica in type 2 Diabetes mellitus. The Bioscan. 2010;5(2):211-214.

82. Pipe EA, Gobert CP, Capes SE, Darlington GA, Lampe JW, Duncan AM. Soy protein reduces serum LDL cholesterol and the LDL cholesterol: HDL cholesterol and apolipoprotein B: apolipoproteinA-I ratios in adults with type 2 diabetes. J Nutr. 2009;139(9):1700-1706. doi:10.3945/jn.109.109595

83. Labban L, Mustafa UE-S, Ibrahim YM. The effects of Rosemary (Rosmarinus officinalis) leaves powder on glucose level, lipid profile and lipid perodoxation. Int $J$ Clin Med. 2014;05 (06):297-304. doi:10.4236/ijcm.2014.56044

84. Esmaillzadeh A, Tahbaz F, Gaieni I, Alavi-Majd H, Azadbakht L. Cholesterol-lowering effect of concentrated pomegranate juice consumption in type II diabetic patients with hyperlipidemia. Int J Vitam Nutr Res. 2006;76(3):147-151. doi:10.1024/0300-9831.76.3.147

85. Rock W, Rosenblat M, Miller-Lotan R, Levy AP, Elias M, Aviram M. Consumption of Wonderful variety pomegranate juice and extract by diabetic patients increases paraoxonase 1 association with high-density lipoprotein and stimulates its catalytic activities. J Agric Food Chem. 2008;56(18):8704-8713. doi:10.1021/ jf801756x

86. Burton-Freeman B, Linares A, Hyson D, Kappagoda T. Strawberry modulates LDL oxidation and postprandial lipemia in response to high-fat meal in overweight hyperlipidemic men and women. J Am Coll Nutr. 2010;29(1):46-54. doi:10.1080/ 07315724.2010 .10719816

87. Liu X, Xue Y, Liu C, et al. Eicosapentaenoic acid-enriched phospholipid ameliorates insulin resistance and lipid metabolism in diet-induced-obese mice. Lipids Health Dis. 2013;12(1):1-10. doi:10.1186/1476-511X-12-109

88. Neschen S, Morino K, Dong J, et al. n-3 fatty acids preserve insulin sensitivity in vivoin a Peroxisome Proliferator - activated Receptor- $\alpha-$ dependent Manner. Diabetes. 2007;56(4):1034 1041. doi:10.2337/db06-1206.2-

89. Flachs P, Horakova O, Brauner P, et al. Polyunsaturated fatty acids of marine origin upregulate mitochondrial biogenesis and induce $\beta$-oxidation in white fat. Diabetologia. 2005;48(11):23652375. doi:10.1007/s00125-005-1944-7

90. Levy BD, Kohli P, Gotlinger K, et al. Protectin D1 Is generated in asthma and dampens airway inflammation and hyperresponsiveness. J Immunol. 2010;178(1):496-502.

91. Mickleborough TD, Tecklenburg SL, Montgomery GS, Lindley MR. Eicosapentaenoic acid is more effective than docosahexaenoic acid in inhibiting proinflammatory mediator production and transcription from LPS-induced human asthmatic alveolar macrophage cells. Clin Nutr. 2009;28(1):71-77. doi:10.1016/j.clnu.20 08.10.012

92. Farrell N, Norris G, Lee SG, Chun OK, Blesso CN. Anthocyaninrich black elderberry extract improves markers of HDL function and reduces aortic cholesterol in hyperlipidemic mice. Food Funct. 2015;6(4):1278-1287. doi:10.1039/c4fo01036a

93. Li D, Zhang Y, Liu Y, Sun R, Xia M. Purified anthocyanin supplementation reduces dyslipidemia, enhances antioxidant capacity, and prevents insulin resistance in diabetic patients. $J$ Nutr. 2015;145(4):742-748. doi:10.3945/jn.114.205674

94. Wolfram S, Raederstorff D, Preller M, et al. Epigallocatechin gallate supplementation alleviates diabetes in rodents. J Nutr. 2006;136(10):2512-2518. doi:10.1093/jn/136.10.2512
95. Cremonini E, Bettaieb A, Haj FG, Fraga CG, Oteiza PI. -)-Epicatechin improves insulin sensitivity in high fat diet-fed mice. Arch Biochem Biophys. 2016;599:13-21. doi:10.1016/j.abb.2016.03.006

96. Moon J, Do HJ, Kim OY, Shin MJ. Antiobesity effects of quercetin-rich onion peel extract on the differentiation of 3T3-L1 preadipocytes and the adipogenesis in high fat-fed rats. Food Chem Toxicol. 2013;58:347-354. doi:10.1016/j.fct.2013.05.006

97. Lee SG, Parks JS, Kang HW. Quercetin, a functional compound of onion peel, remodels white adipocytes to brown-like adipocytes. J Nutr Biochem. 2017;42(2017):62-71. doi:10.1016/j. jnutbio.2016.12.018

98. Gong M, Garige M, Varatharajalu R, et al. Quercetin up-regulates paraoxonase 1 gene expression with concomitant protection against LDL oxidation. Biochem Biophys Res Commun. 2009;379(4):1001-1004. doi:10.1016/j.bbrc.2009.01.015

99. Rivera L, Morón R, Sánchez M, Zarzuelo A, Galisteo M. Quercetin ameliorates metabolic syndrome and improves the inflammatory status in obese Zucker rats. Obesity. 2008;16 (9):2081-2087. doi:10.1038/oby.2008.315

100. Luo C, Yang H, Tang C, et al. Kaempferol alleviates insulin resistance via hepatic IKK/NF- $\kappa \mathrm{B}$ signal in type 2 diabetic rats. Int Immunopharmacol. 2015;28(1):744-750. doi:10.1016/j.intimp. 2015.07.018

101. Zhang Y, Liu D. Flavonol kaempferol improves chronic hyperglycemia-impaired pancreatic beta-cell viability and insulin secretory function. Eur J Pharmacol. 2011;670(1):325-332. doi:10.10 16/j.ejphar.2011.08.011

102. Goto T, Teraminami A, Lee J-Y, et al. Tiliroside, a glycosidic flavonoid, ameliorates obesity-induced metabolic disorders via activation of adiponectin signaling followed by enhancement of fatty acid oxidation in liver and skeletal muscle in obese-diabetic mice. J Nutr Biochem. 2012;23(7):768-776. doi:10.1016/j.jnutbio.2011. 04.001

103. Priscilla DH, Jayakumar M, Thirumurugan K. Flavanone naringenin: an effective antihyperglycemic and antihyperlipidemic nutraceutical agent on high fat diet fed streptozotocin induced type 2 diabetic rats. J Funct Foods. 2015;14:363-373. doi:10.10 16/j.jff.2015.02.005

104. Ahmed OM, Mahmoud AM, Abdel-Moneim A, Ashour MB. Antidiabetic effects of hesperidin and naringin in type 2 diabetic rats. Diabetol Croat. 2012;41(2):53-67.

105. Liu Z, Liu T, Lei $\mathrm{C}$, et al. Novel role of hesperidin improve obesity in HFD mice by modulating the composition of the gut microbiota. Res Sq. 2020. doi:10.21203/rs.2.21089/v1

106. El-Bassossy HM, Abo-Warda SM, Fahmy A. Chrysin and luteolin attenuate diabetes-induced impairment in endothelialdependent relaxation: effect on lipid profile, AGEs and NO generation. Phytother Res. 2013;27(11):1678-1684. doi:10.10 02/ptr.4917

107. El-Bassossy HM, Abo-Warda SM, Fahmy A. Chrysin and luteolin alleviate vascular complications associated with insulin resistance mainly through PPAR- $\gamma$ activation. Am J Chin Med. 2014;42(5):1153-1167. doi:10.1142/S0192415X1450 0724

108. Zhang L, Han Y-J, Zhang X, et al. Luteolin reduces obesityassociated insulin resistance in mice by activating AMPK $\alpha 1$ signalling in adipose tissue macrophages. Diabetologia. 2016;59 (10):2219-2228. doi:10.1007/s00125-016-4039-8

109. Fu Z, Liu D. Long-term exposure to genistein improves insulin secretory function of pancreatic $\beta$-cells. Eur $J$ Pharmacol. 2009;616(1-3):321-327. doi:10.1016/j.ejphar.2009.06.005

110. Hsu CL, Wu CH, Huang SL, Yen GC. Phenolic compounds rutin and o-coumaric acid ameliorate obesity induced by high-fat Diet in rats. J Agric Food Chem. 2009;57(2):425-431. doi:10.1021/ jf802715t 
111. Abdel-Moneim A, SMA E-T, Yousef AI, Reheim ESA, Ashour MB. Modulation of hyperglycemia and dyslipidemia in experimental type 2 diabetes by gallic acid and p-coumaric acid: the role of adipocytokines and PPAR $\gamma$. Biomed Pharmacother. 2018;105:1091-1097. doi:10.1016/j.biopha.2018.06.096

112. Ibitoye OB, Ajiboye TO. Dietary phenolic acids reverse insulin resistance, hyperglycaemia, dyslipidaemia, inflammation and oxidative stress in high-fructose diet-induced metabolic syndrome rats. Arch Physiol Biochem. 2018;124(5):410-417. doi:10.1080/ 13813455.2017.1415938

113. Antunes AEC, Vinderola G, Xavier-Santos D, Sivieri K. Potential contribution of beneficial microbes to face the COVID-19 pandemic. Food Res Int. 2020;136(June):109577. doi:10.1016/j. foodres.2020.109577

114. Dhar D, Mohanty A. Gut microbiota and Covid-19- possible link and implications. Virus Res. 2020;285:198018. doi:10.1016/j. virusres.2020.198018

115. Berggren A, Lazou Ahrén I, Larsson N, Önning G. Randomised, double-blind and placebo-controlled study using new probiotic lactobacilli for strengthening the body immune defence against viral infections. Eur J Nutr. 2011;50(3):203-210. doi:10.1007/ s00394-010-0127-6

116. de Vrese M, Winkler P, Rautenberg P, et al. Probiotic bacteria reduced duration and severity but not the incidence of common cold episodes in a double blind, randomized, controlled trial. Vaccine. 2006;24(44 46):6670-6674. doi:10.1016/j.vaccine.2006.05.048

117. Boge T, Rémigy M, Vaudaine S, Tanguy J, Bourdet-Sicard R. van der Werf S. A probiotic fermented dairy drink improves antibody response to influenza vaccination in the elderly in two randomised controlled trials. Vaccine. 2009;27(41):5677-5684. doi:10.1016/j. vaccine.2009.06.094

118. National US. Library of Medicine. Evaluation of the Probiotic Lactobacillus Coryniformis K8 on COVID-19 Prevention in Healthcare Workers. 2020. Available from: https://clinicaltrials. gov/ct2/show/NCT04366180. Accessed January 15, 2021.

119. U.S. National Library of Medicine. Bacteriotherapy in the Treatment of COVID-19 (BACT-Ovid).. Https://Clinicaltrials. gov/Ct2/Show/Nct04368351. 2020. Available from:.

120. Corrêa-Oliveira R, Fachi JL, Vieira A, Sato FT, Vinolo MAR. Regulation of immune cell function by short-chain fatty acids. Clin Transl Immunol. 2016;5(4):1-8. doi:10.1038/cti.2016.17

121. Li M, BCAM VE, Wagenaar GTM, Garssen J, Folkerts G, Henricks PAJ. Pro- and anti-inflammatory effects of short chain fatty acids on immune and endothelial cells. Eur J Pharmacol. 2018;831:52-59. doi:10.1016/j.ejphar.2018.05.003

122. Venkatakrishnan K, Chiu HF, Wang CK. An extensive review on popular functional foods and nutraceuticals against obesity and its related complications with a special focus on randomized clinical trials. Food Funct. 2019. doi:10.1039/C9FO00293F.Food

123. Chakrabarti S, Wu J. Milk-derived tripeptides IPP (Ile-Pro-Pro) and VPP (Val-Pro- Pro) promote adipocyte differentiation and inhibit inflammation in 3T3-F442A cells. PLoS One. 2015;10 (2):1-15. doi:10.1371/journal.pone.0117492

124. Ortega-González M, Capitán-Cañadas F, Requena P, et al. Validation of bovine glycomacropeptide as an intestinal anti-inflammatory nutraceutical in the lymphocyte-transfer model of colitis. $\mathrm{Br} J$ Nutr. 2014;111(7):1202-1212. doi:10.1017/S0007114513003590

125. Nakamura T, Hirota T, Mizushima K, et al. Milk-derived peptides, ValPro-Pro and Ile-Pro-Pro, attenuate atherosclerosis development in apolipoprotein E-deficient mice: A preliminary study. $J$ Med Food. 2013;16(5):396-403. doi:10.1089/jmf.2012.2541

126. Iskandar MM, Dauletbaev N, Kubow S, Mawji N, Lands LC. Whey protein hydrolysates decrease IL-8 secretion in lipopolysaccharide (LPS)-stimulated respiratory epithelial cells by affecting LPS binding to Toll-like receptor 4. Br J Nutr. 2013;110 (1):58-68. doi:10.1017/S0007114512004655
127. Majumder K, Chakrabarti S, Davidge ST, Wu J. Structure and activity study of egg protein ovotransferrin derived peptides (IRW and IQW) on endothelial inflammatory response and oxidative stress. J Agric Food Chem. 2013;61(9):2120-2129. doi:10.1021/ jf3046076

128. de Mejia EG, Dia VP. Lunasin and lunasin-like peptides inhibit inflammation through suppression of NF- $\mathrm{BB}$ pathway in the macrophage. Peptides. 2009;30(12):2388-2398. doi:10.1016/j. peptides.2009.08.005

129. Kovacs-Nolan J, Zhang H, Ibuki M, et al. The PepT1-transportable soy tripeptide VPY reduces intestinal inflammation. Biochim Biophys Acta - Gen Subj. 2012;1820(11):1753-1763. doi:10.1016/j.bbagen.2012.07.007

130. Bjørndal B, Berge C, Ramsvik MS, et al. A fish protein hydrolysate alters fatty acid composition in liver and adipose tissue and increases plasma carnitine levels in a mouse model of chronic inflammation. Lipids Health Dis. 2013;12(1):1-11. doi:10.1186/ 1476-511X-12-143

131. Zhang Y, Kouguchi T, Shimizu K, Sato M, Takahata Y, Morimatsu F. Chicken collagen hydrolysate reduces proinflammatory cytokine production in C57BL/6.KOR-ApoEsh1 mice. J Nutr Sci Vitaminol (Tokyo). 2010;56(3):208-210. doi:10.3177/jnsv.56.208

132. Suzuki Y, Asano M, Sato K, et al. Wheat gluten hydrolysate alters the progress of hepatic pathology induced by prolonged carbon tetrachloride administration in rat. Biomed Res. 2011;22(4):481-488.

133. Hirai S, Horii S, Matsuzaki Y, et al. Anti-inflammatory effect of pyroglutamyl-leucine on lipopolysaccharide-stimulated RAW 264.7 macrophages. Life Sci. 2014;117(1):1-6. doi:10.1016/j. Ifs. 2014.08 .017

134. Udechukwu MC, Tsopmo A, Mawhinney H, He R, Kienesberger PC, Udenigwe CC. Inhibition of ADAM17/TACE activity by zinc-chelating rye secalin-derived tripeptides and analogues. RSC Adv. 2017;7(42):26361-26369. doi:10.1039/c6ra26678a

135. RML CB, Berrill M, Marik PE. The antiviral properties of vitamin C. Expert Rev Anti Infect Ther. 2020;18:2. doi:10.1080/ 14787210.2020 .1706483

136. Chiscano-Camón L, Ruiz-Rodriguez JC, Ruiz-Sanmartin A, Roca $\mathrm{O}$, Vitamin FR. C levels in patients with SARS-CoV-2-associated acute respiratory distress syndrome. Crit Care. 2020;24:1. doi:10.1186/s13054-020-03249-y

137. Feyaerts AF, Luyten W. Vitamin $\mathrm{C}$ as prophylaxis and adjunctive medical treatment for COVID-19? Nutrition. 2020;110948:79-80. doi:10.1016/j.nut.2020.110948

138. Hiedra R, Lo KB, Elbashabsheh M, et al. The Use of IV vitamin $\mathrm{C}$ for patients with COVID-19: a single center observational study. Expert Rev Anti Infect Ther. 2020;18(12):1259-1261. doi:10.1080/14787210.2020.1794819

139. RML CB, Berrill M, Catravas JD, Marik PE. Quercetin and Vitamin C: an experimental, synergistic therapy for the prevention and treatment of SARS-CoV-2 related disease (COVID-19). Front Immunol. 2020. doi:10.3389/fimmu.2020.01451

140. Davis JM, Murphy EA, McClellan JL, Carmichael MD, Gangemi JD. Quercetin reduces susceptibility to influenza infection following stressful exercise. Am J Physiol - Regul Integr Comp Physiol. 2008;295(2):505-509. doi:10.1152/ajpregu.90319.2008

141. Arslan B, Ucuncu Ergun N, Topuz S, et al. Synergistic Effect of Quercetin and Vitamin C Against COVID-19: is a Possible Guard for Front Liners. SSRN Electron J. 2020. doi:10.2139/ssrn.3682517

142. Grant WB, Lahore H, McDonnell SL, et al. Evidence that vitamin D supplementation could reduce risk of influenza and covid-19 infections and deaths.. Nutrients. 2020;12(4):1-19. doi:10.3390/ nu12040988

143. Arboleda JF, Urcuqui-Inchima S. Coronavirus covid-19 has killed more people than SARS and MERS combined, despite lower case fatality rate. Front Immunol. 2020;11(1523):1-4. doi:10.1136/ bmj.m641 
144. Ebadi M, Montano-Loza AJ. Perspective: improving vitamin D status in the management of COVID-19. Eur J Clin Nutr. 2020;74 (6):856-859. doi:10.1038/s41430-020-0661-0

145. Ghavideldarestani M, Honardoost M, Khamseh ME. Role of Vitamin D in Pathogenesis and Severity of Coronavirus Disease 2019 (COVID-19) Infection. Pakistan J Med Heal Sci. 2020;14 (2):462-465. doi:10.20944/preprints202004.0355.v1
146. U.S. National Library of Medicine. Utility of Lactoferrin as an Adjunct Therapeutic Agent for COVID-19; 2020. Available from:: https://clinicaltrials.gov/ct2/show/NCT04421534. Accessed January $15,2021$.

\section{Publish your work in this journal}

Nutrition and Dietary Supplements is an international, peerreviewed, open access journal focusing on research into nutritional requirements in health and disease, impact on metabolism and the identification and optimal use of dietary strategies and supplements necessary for normal growth and development. The journal welcomes submitted papers covering original research, basic science, clinical \& epidemiological studies, reviews and evaluations, guidelines, expert opinion and commentary, case reports and extended reports. The manuscript management system is completely online and includes a very quick and fair peer-review system, which is all easy to use. Visit http://www.dovepress.com/testimonials.php to read real quotes from published authors. 